\title{
Stećci u Općini Čitluk
}

Dijana Korać

Filozofski fakultet

Matice hrvatske b.b.

$\mathrm{BiH}-88000$ Mostar

E-mail: dijana.korac@ff.sum.ba

Ružıca MiRKović

Ulica kralja Tomislava 107

$\mathrm{BiH}-88260$ Čitluk

E-mail:mirkovicruzica@gmail.com

\author{
UDK: 726.825(497.6 Čitluk) \\ 902 (497.6 Čitluk) \\ Izvorni znanstveni rad \\ Primljeno: 11. travnja 2018. \\ Prihvaćeno: 30. svibnja 2018.
}

\section{Sažetak}

U radu se donose rezultati terenskoga istraživanja kojima se revidira broj srednjovjekovnih nadgrobnih spomenika - stećaka na području Općine Čitluk. Ovi se rezultati uspoređuju s rezultatima dosadašnjih istraživanja, pri čemu su evidentne velike razlike u broju stećaka, ali i zastupljenosti pojedinih oblika stećaka. Osim toga, evidentirano je još nekoliko lokaliteta sa stećcima koji se u ovome radu prvi put spominju.

Ključne riječi: Čitluk; Brotnjo; stećci; oblici stećaka; nekropole. 


\section{Uvod}

Na području današnjega Brotnja, ${ }^{1}$ odnosno u Općini Čitluk, očuvan je velik broj srednjovjekovnih nadgrobnih spomenika na više lokaliteta. Pri istraživanju stećaka bilo kojega područja Bosne i Hercegovine nezaobilazno polazište svakome istraživaču svakako su rezultati istraživanja Šefika Bešlagića, ${ }^{2}$ a osim njega, velik doprinos proučavanju stećaka u $\mathrm{BiH}$ dali su i drugi znanstvenici. ${ }^{3}$ Valja napomenuti

1 Srednjovjekovno Brotnjo, koje je bilo u sastavu humske župe Večerić, obuhvaćalo je još neka naselja koja danas ne pripadaju Općini Čitluk. O povijesti srednjovjekovnoga Brotnja, između ostalih, pisali su: MARKo VeGo, Historija Broćna od najstarijih vremena do turske okupacije, Narodni odbor Općine Čitluk, Sarajevo, 1961.; Marko Vego, Historija Brotnja od najstarijih vremena do 1878. godine, Skupština općine Čitluk, Čitluk, 1981.; MARIJAN Sivrić, "Nekoliko najstarijih vijesti o Broćnu - Brotnju i njegovu imenu", u: Brotnjo prvi zbornik, Matica hrvatska ogranak Čitluk - Općina Čitluk, Čitluk, 1997., str. 7-21; Marijan Sivrić, "Nekoliko najstarijih vijesti o Broćnu - Brotnju u humskoj župi Večerići i njegovu imenu", u: Brotnjo. Zbornik 4, Matica hrvatska Čitluk - Općina Čitluk, Čitluk, 2006., str. 7-23; SkupinA AUTORA, Međugorje $i$ Bijakovići u Brotnju, Mjesna zajednica Međugorje, Međugorje, 1979.; RoBERT Jolić, Župa Krista Kralja u Čitluku. Spomen knjiga prigodom 90. obljetnice uspostave župe (1918/20.-2010.), Župni ured Čitluk - Naša ognjišta, Čitluk Tomislavgrad, 2010.; Dijana Korać, "Područje Brotnja (Broćna) u srednjem vijeku", u: Dario Dodig - Dijana Korać (prir.), Župa Čerin. 150. obljetnica osnutka župe (1864.-2014.), Naša ognjišta - Župni ured Čerin, Tomislavgrad Čerin, 2014., str. 39-56; ANTE ŠKEgRO, "Brotnjom od pretpovijesti do srednjega vijeka", u: DARIo Dodig - DijAna Korać (prir.), Župa Čerin. 150. obljetnica osnutka župe (1864.-2014.), Naša ognjišta - Župni ured Čerin, Tomislavgrad - Čerin, 2014., str. 15-26.

2 Riječ je o knjigama: ŠEFIK BeŠLagić, Stećci. Kataloško-topografski pregled, Veselin Masleša, Sarajevo, 1971.; ŠEFIK BeŠLAGIĆ, Stećci - kultura i umjetnost, Veselin Masleša, Sarajevo, 1982.; ŠEFIK BeŠLAGIĆ, Leksikon stećaka, Svjetlost, Sarajevo, 2004. Važno je spomenuti da je prije njega vrijedne podatke o ovim srednjovjekovnim spomenicima na području Brotnja donio M. Vego (Historija Broćna od najstarijih vremena do turske okupacije), pa se Bešlagić često poziva na Vegu u opisima nekih lokaliteta. Mi ćemo, pak, u ovome radu svoje rezultate uspoređivati s rezultatima koje je Vego iznio u knjizi novijega izdanja s naslovom: Historija Brotnja od najstarijih vremena do 1878. godine.

3 Iz obilne literature o stećcima navest ćemo samo neke naslove: AloJZ BENAC, Radimlja, Izdanje Zemaljskog muzeja u Sarajevu, Sarajevo, 1950.; Arheološki leksikon Bosne i Hercegovine, sv. III., Zemaljski muzej u Sarajevu, Sarajevo, 1988.; Branka Purgarić-KuŽić, "Dosadašnja istraživanja o stećcima", u: Radovi Zavoda za hrvatsku povijest Filozofskoga fakulteta Sveučilišta u Zagrebu, 28, Zagreb, 1995., str. 242-253; Dubravko Lovrenović, Stećci. Bosansko i 
da su u novije vrijeme stećci vrlo zanimljivi brojnim istraživačima, koji najčešće u sklopu različitih projekata opisuju srednjovjekovne nekropole stećaka i revidiraju njihov broj, a njihove rezultate, osim u radovima znanstvenih časopisa, možemo vidjeti i u monografijama župa, općina i slično. ${ }^{4}$ Osim znanstvenika, ovi srednjovjekovni spomenici privukli su i veću pažnju lokalnih vlasti pa se u novije vrijeme u pojedinim općinama pristupa njihovu revidiranju i zaštiti, što vidimo i na području ove Općine, koja je 2012. godine pokrenula projekt obilježavanja, čišćenja i zaštite ovih spomenika čiji rezultati još nisu u cijelosti objavljeni. ${ }^{5}$

Cilj ovoga rada jest prikazati rezultate terenskoga istraživanja ${ }^{6}$ kojim se revidira broj srednjovjekovnih nadgrobnih spomenika - stećaka i nekropola na području Općine Čitluk, te potaknuti na daljnje istraživanje i adekvatnu valorizaciju i zaštitu ove vrijedne kulturne baštine. Naime, uvidom na terenu zamijećene su velike razlike u opisu mnogih nekropola između dosadašnjih rezultata u historiografiji i rezultata ovih istraživanja i to prije svega u broju stećaka te njihovu

humsko mramorje srednjeg vijeka, Rabic, Sarajevo, 2009.; JASMinka PokLEČKI STošić (ur.), Stećci. Katalog izložbe, Zagreb, 4. rujna 2008. - 2. studenoga 2008., Galerija Klovićevi dvori, Zagreb, 2008.

4 Detaljne opise lokaliteta na području župa Čitluk, Međugorje i Gradnići u novije vrijeme objavio je R. Jolić, a stećcima u Vionici bavio se Anđelko Zelenika i Kornelije Kordić. O tome vidjeti u: R. Jolıć, Župa Krista Kralja u Čitluku; Robert Jolić, Župa Međugorje. 120 godina samostalnog života (1892.-2012.), Informativni centar "Mir" Međugorje, Međugorje, 2013.; Robert Jolić, Župa Brotnjo - Gradnići, Naša ognjišta, Tomislavgrad, 2018.; AnĐElko ZeleniKA, "Stećci s područja Vionice. Prilog proučavanju prošlosti Brotnja", u: Brotnjo. Zbornik 2, Matica hrvatska Čitluk, Čitluk, 1998., str. 41-47; Kornelıje KorDIĆ, Vionica, FRAM Mostar, Mostar, 2001., str. 157-164. Također, u novije vrijeme na neke nekropole u župi Gradnići prvi je ukazao I. Dugandžić. O tome: Ivan Dugandžıć, "Nekropole stećaka u župi Gradnići", u: Brotnjo. Zbornik 5, Matica hrvatska Čitluk, Brotnjo - Čitluk, 2008., str. 230-234.

5 http://citluk.net/, Stećci u Brotnju: Čišćenje, obilježavanje i zaštita svih lokacija sa stećcima (7. 4. 2017.).

6 Od Zavoda za zaštitu kulturno-povijesne baštine Hercegovačko-neretvanske županije dobili smo dozvolu za rad na revidiranju nekropola stećaka te službeni popis srednjovjekovnih nalazišta Općine Čitluk čiji su podatci uglavnom isti kao u Arheološkome leksikonu Bosne i Hercegovine. Ovom prilikom zahvaljujemo ravnateljici Zavoda za zaštitu kulturno-povijesne baštine Hercegovačko-neretvanske županije mr. sc. Ivanki Miličević-Capek i pripravnici Dijani Krešić koje su izvršile provjeru stanja određenoga broja nekropola. 
obliku. ${ }^{7}$ Osim toga, evidentirano je još nekoliko lokaliteta sa stećcima koji se u ovome radu prvi put spominju. Nove smo lokalitete nazvali prema njihovu nazivu u katastru, a također, neke do sada neprecizno ubicirane ili neimenovane lokalitete imenovali smo prema nazivima zemljišnih čestica na kojima se nalaze. Uza svaki lokalitet iznose se podatci o broju stećaka, njihovu obliku te smjeru pružanja. Također, uza svaku nekropolu navest ćemo i ukrase ${ }^{8}$ kao i natpise ${ }^{9}$ na stećcima, $\mathrm{s}$ napomenom da se ukrasima i natpisima ne bavimo $\mathrm{u}$ ovome radu, nego te podatke ukratko iznosimo kako bi slika o svakoj pojedinoj nekropoli bila što jasnija.

7 Želimo napomenuti da se razni autori drže različite klasifikacije, pa je to jedan od razloga u neslaganju broja određenih oblika na nekoj nekropoli. Naime, prema Bešlagiću svaki stećak visine iznad $30 \mathrm{~cm}$ je sanduk, dok A. Benac gornju granicu za ploče stavlja $40 \mathrm{~cm}$. Međutim, čitajući literaturu o stećcima evidentno je da se mnogi autori ne pridržavaju u potpunosti niti jedne od ovih klasifikacija i prave odstupanja, i to na temelju dojma stečenog na terenu. Osim toga, i sam Bešlagić se nije toga u potpunosti pridržavao jer je nekada nadgrobne spomenike više od $30 \mathrm{~cm}$ evidentirao kao ploče, što smo usporedbom rezultata zamijetili na nekim nekropolama. Također, i Benac je ponekad odstupio od predložene klasifikacije, i to zbog osobnoga dojma na samom terenu, jer kako navodi "ponekad odnos dužine i širine daje drugačiji izgled spomeniku nego što bi se prema visini moglo zaključiti". Usp. A. BENAC, Radimlja, str. 28-29; Š. BEŠLAGIĆ, Stećci. Kataloško-topografski pregled, str. 35-36. Ovdje napominjemo da smo od "Bešlagićeve" klasifikacije odstupili jedino u nekoliko slučajeva kada je visina stećka maksimalno $40 \mathrm{~cm}$ a ta visina je manja od 1/3 njegove širine, jer u takvim slučajevima zbog izrazite širine zaista ima izgled ploče, pa smo mišljenja da bi i to trebalo uzimati u obzir prilikom određivanja oblika.

8 O ukrasnim motivima na stećcima više u: MARIAN Wenzel, Ukrasni motivi na stećcima - ornamental motifs on tombstones from medieval Bosnia and surrounding regions, Veselin Masleša, Sarajevo, 1965.; Š. BEŠLAGIć, Stećci - kultura i umjetnost, str. 129-389; Š. BEŠLAGIĆ, Stećci. Kataloško-topografski pregled, str. 50-53; D. Lovrenović, Stećci. Bosansko i humsko mramorje srednjeg vijeka, str. 62-68; PAVAO AnĐElić, "Doba srednjovjekovne bosanske države", u: Kulturna istorija Bosne i Hercegovine (od najstarijih vremena do pada ovih zemalja pod osmansku vlast), Veselin Masleša, Sarajevo, ${ }^{2} 1984$., str. 488-491.

9 Od 11 natpisa na stećcima na području srednjovjekovnoga Brotnja, 8 ih se nalazi na području Općine Čitluk. Najveći broj natpisa (4) nalazi se na nekropoli "Visočica", a ostali natpisi nalaze se u Cerinu, Paoči, Gradnićima i u Služnju. O natpisima na stećcima vidjeti u: Marko Vego, "Novi i revidirani ćirilski natpisi iz župe Broćno u Hercegovini", u: Glasnik Zemaljskog muzeja u Sarajevu, n. s. arh., sv. XIV., Sarajevo, 1959., str. 221-237; Marko Vego, Zbornik srednjovjekovnih natpisa Bosne i Hercegovine, sv. I., Izdanje Zemaljskog muzeja, Sarajevo, 1962.; Marko Vego, Iz istorije srednjovjekovne Bosne i Her- 


\section{Rezultati istraživanja}

Najprije valja napomenuti kako točan broj ovih nadgrobnih spomenika u BiH još nije utvrđen, a popisi Š. Bešlagića već se godinama sustavno revidiraju. Prema Bešlagićevu popisu u $\mathrm{BiH}$ postoji 2687 lokaliteta s ukupno 59.593 pojedinačnih stećaka, ${ }^{10}$ dok se na području Općine Čitluk, prema ovom popisu, nalazi 32 lokaliteta na kojima su pobrojana 703 stećka. ${ }^{11} \mathrm{~S}$ druge strane, u Arheološkome leksikonu Bosne i Hercegovine koji je navedeni Bešlagićev popis dopunio, na području ove Općine spominju se 44 lokaliteta sa 655 srednjovjekovnih nadgrobnih spomenika. ${ }^{12}$ Rezultate do kojih smo došli na terenu usporedili smo s rezultatima dosadašnjih istraživanja, a donosimo ih prema abecednome redu naselja.

cegovine, Svjetlost, Sarajevo, 1980., str. 142-164; M. VEGo, Historija Brotnja od najstarijih vremena do 1878. godine, str. 131-141; MARINKa Šimić, "Jezik natpisa na stećcima u Brotnju", u: Brotnjo. Zbornik 4, Brotnjo - Čitluk, 2006., str. 49-77; MARINKA ŠImIĆ, Jezik srednjovjekovnih kamenih natpisa iz Hercegovine, Matica hrvatska, Sarajevo, 2009.; ŠEFIK BEŠLAGIć, Ćirilički epigrafski spomenici srednjovjekovne Bosne i Hercegovine, Društvo za proučavanje srednjovjekovne bosanske historije - Stanak, Sarajevo, 2015.; Š. BEŠLAGIĆ, Stećci - kultura i umjetnost, str. 419-452; Alija Isaković - Milosav Popadić (ur.), Pisana riječ u Bosni i Hercegovini (od najstarijih vremena do 1918. godine) The written word in Bosnia and Herzegovina (from earliest times up to 1918), Veselin Masleša, Sarajevo, 1982., str. 80-84.

10 Š. BEŠLAGIĆ, Leksikon stećaka, str. 165.

11 Š. BeŠlagić, Stećci. Kataloško-topografski pregled, str. 314-317, 340-341.

12 Arheološki leksikon Bosne i Hercegovine, sv. III., str. 290-308. Većinu lokaliteta opisala je Nada Miletić, a neke lokalitete opisali su Petar Oreč, Boško Marijan i Tomislav Anđelić. U smislu razjašnjavanja velikoga odstupanja u broju lokaliteta između Bešlagića i navedenih autora, treba napomenuti kako je primjerice Bešlagić evidentirao određene stećke pod jednim lokalitetom dok su u Arheološkome leksikonu Bosne i Hercegovine ti nadgrobni spomenici navedeni odvojeno (na dva ili tri lokaliteta). S druge strane, treba kazati i da se autori u Arheološkome leksikonu Bosne i Hercegovine u opisima mnogih lokaliteta pozivaju na rezultate Š. Bešlagića i M. Vege, ali su ovdje evidentirane i neke nekropole koje se ne spominju u dvojice ranije navedenih autora. Spomenimo i da broj od oko 720 stećaka na području Brotnja donosi I. Dugandžić, koji se poziva na članak K. Kordića u kojemu se nalaze podatci o ovim srednjovjekovnim spomenicima na području Brotnja (identični onima iz Arheološkoga leksikona Bosne i Hercegovine) s tim da treba napomenuti da su tu navedeni i stećci u nekim naseljima koja danas ne pripadaju Općini Čitluk. Usp. I. DuGANDžıć, "Nekropole stećaka u župi Gradnići", str. 232; Kornelije Kordić, "Nalazišta i povijesna mjesta u Brotnju", u: Brotnjo. Zbornik 2, Čitluk, 1998., str. 9-36. 
U Biletić Polju nalaze se dva osamljena bogato ukrašena stećka (jedan visoki sanduk s postoljem i križ u kombinaciji s pločom). Ove su stećke već ranije evidentirali Š. Bešlagić, N. Miletić te $M$. Vego koji se posebno osvrnuo na ljepotu ovoga sanduka, donoseći detaljne opise ukrasa na njemu. ${ }^{13}$ Orijentacija ovih stećaka je u smjeru s-j. Ploča je ukrašena vinovom lozicom $s$ trolistom. $S$ istočne strane sanduk je bogato ukrašen frizom sa scenom lova na jelena, dok se na sjevernoj i južnoj strani nalaze prikazi muškoga i ženskoga kola.

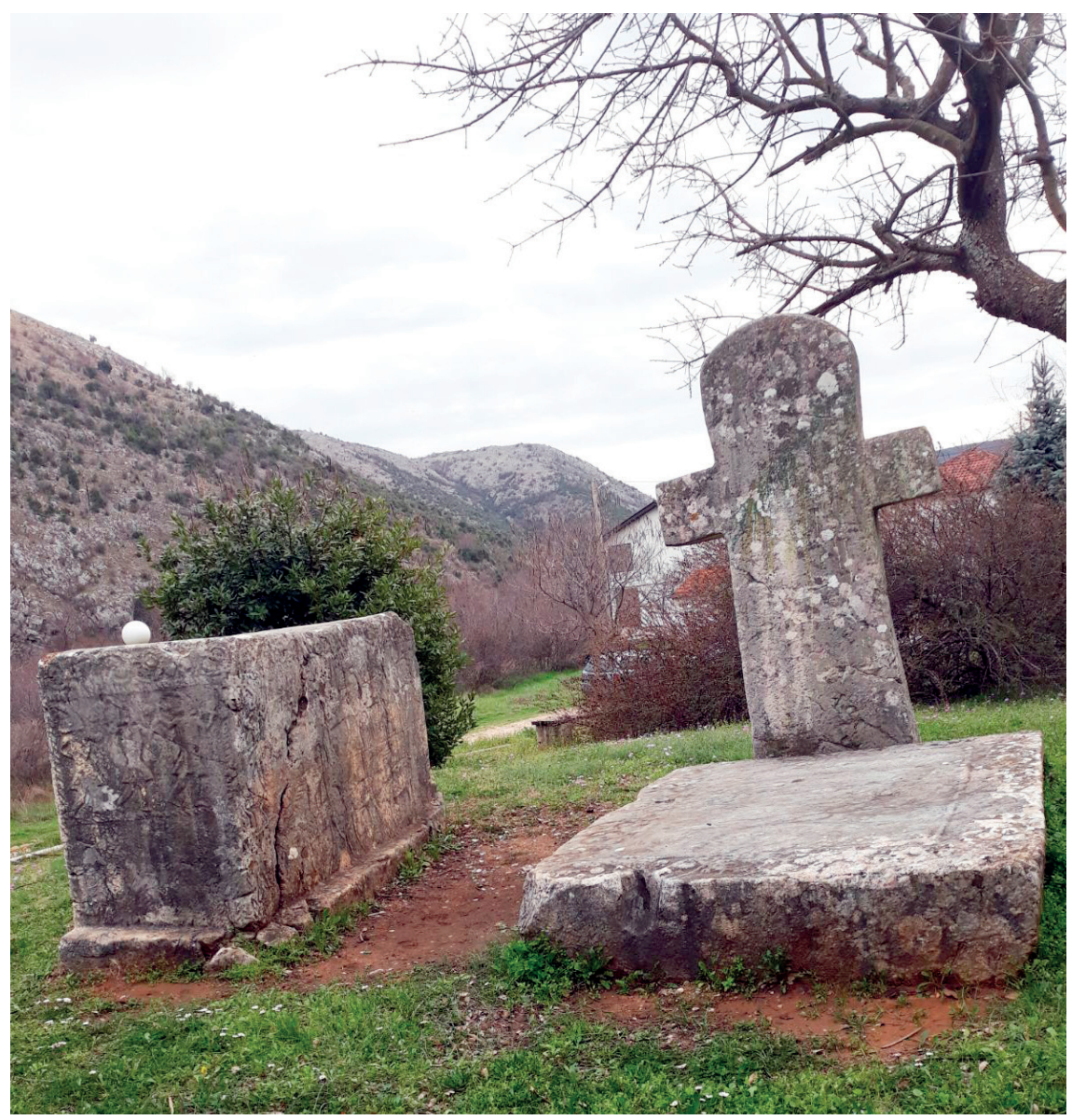

Stećci u Biletić Polju (foto: D. Korać)

13 Š. BeŠLAGić, Stećci. Kataloško-topografski pregled, str. 340; Arheološki leksikon Bosne i Hercegovine, sv. III., str. 309; M. VEGo, Historija Brotnja od najstarijih vremena do 1878. godine, str. 158-159. 


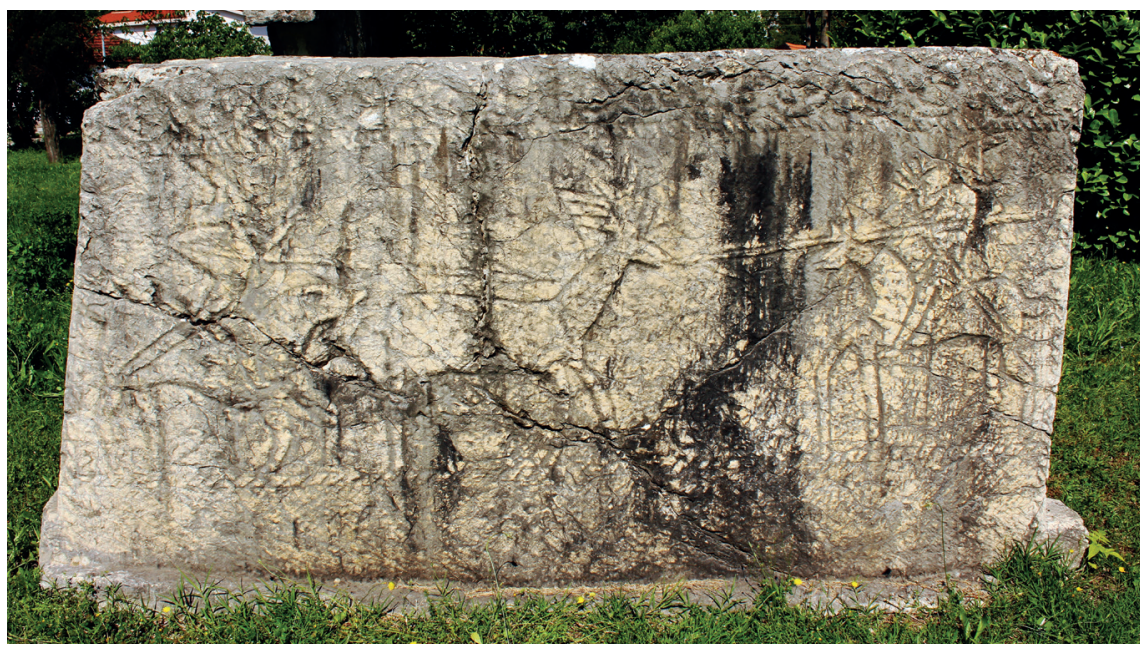

Ukrasni motivi na visokom sanduku u Biletić Polju (foto: R. Mirković)

U Blatnici stećke nalazimo u starom groblju "Bakri", ${ }^{14}$ gdje se nalaze 2 stećka (jedan u obliku sanduka a drugi je utonuo u zemlju) postavljena u smjeru z-i. Spomenici su bez ukrasa. Također, u selu Blatnica (Gornja) nalazi se jedan stećak koji je u novije vrijeme evidentiran na lokalitetu "Pilipa busić". ${ }^{15}$ Stećak ima oblik ploče $(250$ x 220 x $40 \mathrm{~cm})$, a na gornjoj plohi od ukrasa se nalaze bordura i rozeta.

U selu Blizanci postoje dva lokaliteta sa stećcima. Lokalitet koji je u Arheološkome leksikonu Bosne i Hercegovine ${ }^{16}$ evidentiran pod nazi-

14 Ovi stećci nisu evidentirani u Bešlagića, a R. Jolić u svom prilogu o grobljima u župi Čerin spominje stećak u obliku sanduka. RoBERT Jolić, "Groblja u čerinskoj župi", u: Dario Dodig - Dijana Korać (prir.), Župa Čerin. 150. obljetnica osnutka župe (1864.-2014.), Naša ognjišta - Župni ured Čerin, Tomislavgrad - Čerin, 2014., str. 194.

15 Prvi ga je evidentirao tadašnji župnik fra Marinko Šakota 2006. godine. Nakon toga podatke o stećku donosi I. Dugandžić, a u najnovije vrijeme detaljno ga je opisao R. Jolić. O tome vidi: I. DugAndžıć, "Nekropole stećaka u župi Gradnići", str. 233-234; R. Jolıć, Župa Brotnjo - Gradnići, str. 45. Stećak se nalazi na zemljišnoj parceli s nazivom "Njiva". http://www.katastar.ba/geoportal/ preglednik/ (29. 3. 2018.).

16 Usp. Arheološki leksikon Bosne i Hercegovine, sv. III., str. 300. Valja napomenuti da M. Vego spominje u Krehinu Gracu lokalitet s jednim većim sljemenjakom koji se nalazi na brijegu pokraj glavnoga puta za Mostar (na lijevoj strani). Sudeći prema opisu mjesta i nadgrobnoga spomenika, a i s obzirom na činjenicu da su Krehin Gradac i Blizanci susjedna naselja, vjerojatno se radi 
vom "Kordića lokve" nalazi se na zemljišnoj parceli zvanoj "Grlica", ${ }^{17}$ a riječ je o masivnijem sljemenjaku s postoljem bez vidljivih ukrasa. Ovaj je stećak prilikom izgradnje kanalizacije pomaknut s prvobitnoga položaja. Drugi lokalitet u Blizancima nalazi se pokraj puta za Mostar na zemljišnoj čestici s nazivom "Stećak", ${ }^{18}$ a na njoj se nalazi nekropola s minimalno 5 stećaka, koja je zarasla u raslinje, zapuštena i nepristupačna. Riječ je vjerojatno o nekropoli "Stećci" koja je pod ovim imenom evidentirana u Arheološkome leksikonu Bosne i Hercegovine gdje prema navodu N. Miletić stoji da se na ovoj nekropoli nalazi 7 stećaka u obliku sanduka postavljenih u smjeru z-i, a spominje se i motiv križa. ${ }^{19} \mathrm{Na}$ žalost, ove navode zbog nepristupačnosti terena nismo mogli provjeriti.

Nekropolu stećaka s nazivom istoimenoga naselja "Čalići" evidentirala je N. Miletić (Arheološki leksikon Bosne i Hercegovine), gdje je zabilježila 4 stećka u obliku ploče i sanduka. ${ }^{20} \mathrm{Na}$ terenu smo evidentirali 4 stećka ( 3 sanduka i 1 ploča ukrašena jednostavnom trakicom koja dijeli gornju plohu stećka na dva dijela), koja se nalaze između dvije parcele koje nose naziv "Groblje". ${ }^{21}$ Stećci su obrađeni i očuvani, a postavljeni su u smjeru z-i.

U Čerinu se nalaze tri lokaliteta sa stećcima. Prvi lokalitet evidentiran je pokraj tamošnje crkve. ${ }^{22}$ Vezano uz ovaj lokalitet Bešlagić piše kako se ovdje nalaze 3 stećka u obliku sanduka, od čega su dva "ugrađena u zgradu samostana i u ogradni podzid", a posebno ističe onaj s natpisom Radovana Rakojevića. Iste podatke nalazimo i u Arheološkome leksikonu Bosne i Hercegovine pod nazivom lokalitet "Čerin 1". Osim ovih stećaka, Bešlagić spominje i jedan starokršćanski

o istom lokalitetu. Usp. M. Vego, Historija Brotnja od najstarijih vremena do 1878. godine, str. 151.

17 http://www.katastar.ba/geoportal/preglednik/ (25. 3. 2018.).

18 http://www.katastar.ba/geoportal/preglednik/ (25. 3. 2018.).

19 Arheološki leksikon Bosne i Hercegovine, sv. III., str. 305.

20 Arheološki leksikon Bosne i Hercegovine, sv. III., str. 293.

21 http://www.katastar.ba/geoportal/preglednik/ (25. 3. 2018.).

22 Zemljišna parcela na kojoj se nalaze ovi stećci zove se "Dvorište". http://www. katastar.ba/geoportal/preglednik/ (24. 3. 2018.). Podatke o ovome lokalitetu nalazimo u: Š. Bešlagić, Stećci. Kataloško-topografski pregled, str. 314; M. VEGo, Historija Brotnja od najstarijih vremena do 1878. godine, str. 143; Arheološki leksikon Bosne i Hercegovine, sv. III., str. 293. 
sarkofag i nekoliko antičkih fragmenata, te navodi kako se u blizini ove nekropole, usred naselja, nalaze dva korita za česmu, napravljena od stećaka u obliku sanduka bez ukrasa. S druge strane, Vego donosi različite podatke te spominje 6 stećaka u obliku sanduka i dva sljemenjaka. ${ }^{23}$ Danas se na ovome lokalitetu nalazi 1 sljemenjak (oštećen a na njemu se nalazi motiv križa), 1 sanduk impozantnih dimenzija s natpisom Radovana Rakojevića, 3 neukrašena sanduka od kojih je jedan oštećen. Osim ovih stećaka koji se nalaze in situ, iz razgovora $s$ mještaninom Zdravkom Petrinom doznali smo da su prilikom preuređenja i širenja crkvenoga dvorišta ovdje premještena i 3 stećka koji su bili u sekundarnoj uporabi. Radi se o "dva korita za česmu" koja spominje Š. Bešlagić, te još jedno koje je stajalo pokraj česme ispred župne kuće, a osim njih u crkvenome dvorištu nalazio se još jedan stećak koji je prekriven betonskom pločom prilikom izgradnje čatrnje pokraj župne kuće. ${ }^{24}$ Svojom ljepotom i danas se posebno ističe sanduk s natpisom Radovana Rakojevića na kojemu je uklesan natpis (danas slabo vidljiv): "A sei leži Radovan Rakoivić. Proklet' ko će tućin (tuđin) leč (leći) veće negovo pleme". ${ }^{25}$ Ovaj stećak ukrašen je s tri rozetice, motivom mača sa štitom, te uokviren trakom od vinove lozice s trolistovima. Na stećak je u novije vrijeme postavljen rimski nadgrobni spomenik. Dok je ovaj stećak postavljen u karakterističnom smjeru z-i, ostali spomenici orijentirani su u smjeru s-j.

Drugi čerinski lokalitet nalazi se u polju gdje je Bešlagić više skupina objedinio u jednu nekropolu i pribrojio Cerinu. Prema Bešlagiću na

23 Š. BeŠLAGić, Stećci. Kataloško-topografski pregled, str. 314; Arheološki leksikon Bosne i Hercegovine, sv. III., str. 293; M. VEGo, Historija Brotnja od najstarijih vremena do 1878. godine, str. 143.

24 Navedeno prema riječima Zdravka Petrine (6. 4. 2018.).

25 Navedeno prema: M. Vego, Historija Broćna od najstarijih vremena do turske okupacije, str. 86. Nakon istraživanja koje je obavio na lokalitetu 1957. godine Vego je donio detalje o ovome stećku i natpisu. O tome više u: M. VEGo, "Novi i revidirani ćirilski natpisi iz župe Broćno u Hercegovini", str. 224-226; M. VEGo, Zbornik srednjovjekovnih natpisa Bosne i Hercegovine, sv. I., str. 19; M. Vego, Iz istorije srednjovjekovne Bosne i Hercegovine, str. 146-148. Usp. M. Šimıć, "Jezik natpisa na stećcima u Brotnju", str. 60; M. Šımı́́, Jezik srednjovjekovnih kamenih natpisa iz Hercegovine, str. 87-88. Ovaj natpis završava formulom sankcije koja je preuzeta iz suvremenih ćiriličnih povelja. O tome, kao i o eshatološkoj formuli "a se leži" (u iščekivanju uskrsnuća) na stećcima vidjeti više u: Dubravko Lovrenović, "Epitafi - 'knjige života"', u: JASMinkA PoKlečKi Stošić (ur.), Stećci. Katalog izložbe, Zagreb, 4. rujna 2008. - 2. studenoga 2008., Galerija Klovićevi dvori, Zagreb, 2008., str. 204-207. 


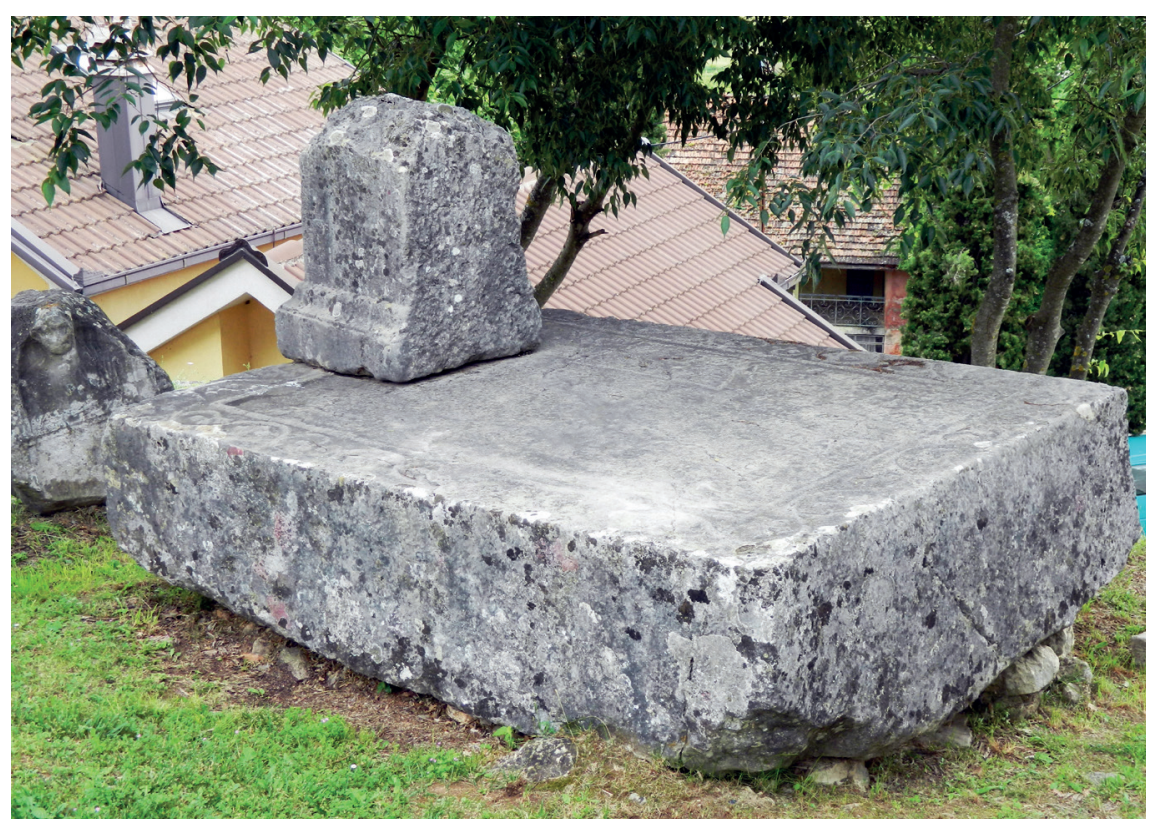

Stećak Radovana Rakojevića u Čerinu (foto: D. Korać)

ovoj nekropoli nalazi se 36 stećaka (35 sanduka i 1 sljemenjak) raspoređenih u četiri skupine. Tu se nalazio i sljemenjak s predstavom ptica (sokoli) te figurom čovjeka koji je prenesen u Zemaljski muzej u Sarajevo. ${ }^{26}$ Prema ranijim opisima spomenici su vrlo dobro obrađeni, a jedan broj spomenika pomaknut je i zatrpan zemljom. Ukrašeno je 12 stećaka (1 sljemenjak i 11 sanduka), i to motivima bordure od povijene lozice sa spiralicama, bordurom od cik-cak linija s umetcima u obliku sidra, frizom od kosih crtica i od povijene lozice sa spiralicama, štitom s mačem, rozetama, mladim mjesecom, antropomorfnim križem, predstavom konjanika i scenom kola sa 6 ženskih figura. ${ }^{27} \mathrm{~S}$ druge strane, N. Miletić u Arheološkome leksikonu Bosne i Hercegovine ispravno je evidentirala ove stećke pod dvije nekropole imenovane kao "Čerin 2" (12 stećaka), i "Glavica, Mali Ograđenik,

26 Š. BeŠLAGIć, Stećci. Kataloško-topografski pregled, str. 314. Opis stećaka prema M. Vegi pogledati u: M. Vego, Historija Brotnja od najstarijih vremena do 1878. godine, str. 145-146.

27 Š. BeŠLagić, Stećci. Kataloško-topografski pregled, str. 314; M. VEGo, Historija Brotnja od najstarijih vremena do 1878. godine, str. 146. 
Gornji Ograđenik" (24 stećka). ${ }^{28}$ Uvidom na terenu može se vidjeti da je riječ zaista o dva lokaliteta s veoma malom udaljenošću, od kojih jedan s manjim brojem srednjovjekovnih spomenika katastarski pripada Čerinu, a drugi s većim brojem stećaka pripada Malom Ograđeniku. Stećci koji katastarski pripadaju Čerinu nalaze se na zemljišnim česticama koje nose nazive "Steljci" i "Begovac". ${ }^{29}$ Također, valja napomenuti da je više stećaka zatrpano kamenjem i obraslo raslinjem te je stoga upitan njihov konačan broj. Na lokalitetu nalazimo 15 stećaka, koji su uglavnom orijentirani u smjeru z-i, osim tri stećka postavljena u smjeru j-s. Radi se uglavnom o sanducima (9) od kojih je jedan masivni sanduk (dimenzija 209 x 168 x $110 \mathrm{~cm}$ ). Nekoliko stećaka zatrpano je kamenjem i obraslo raslinjem. Dva su sanduka ukrašena. Naime, gornja ploha jednoga stećka uokvirena je tordiranom trakom, a na stećku se nalazi također i motiv polumjese$\mathrm{ca},{ }^{30}$ te mač i štit. Na drugom sanduku nalaze se motivi: ukras mač sa štitom, tordirana traka, mladi mjesec i rozeta.

$\mathrm{Na}$ katoličkom groblju u Čerinu, ${ }^{31}$ a nedaleko od župne crkve, sačuvan je jedan stećak koji nije bio evidentiran u ranijoj literaturi. Naime, tek ga u novije vrijeme spominje R. Jolić, koji pišući o grobljima u čerinskoj župi, zaključuje kako i ovo groblje čuva kontinuitet pokapanja od srednjega vijeka sve do danas. ${ }^{32}$ Riječ je o ploči vrlo malih dimenzija, orijentacije z-i, na kojoj nema nikakvih ukrasa.

28 Navodeći podatke o stećcima na ovim lokalitetima Miletić upućuje na Bešlagića koji ih navodi kao veliku nekropolu u Čerinu. Arheološki leksikon Bosne $i$ Hercegovine, sv. III., str. 293-294. Katastarskom provjerom utvrđeno je da drugi lokalitet s nazivom "Glavica" pripada naselju Mali Ograđenik. http:// www.katastar.ba/geoportal/preglednik/ (24.3. 2018.).

29 Ovdje valja napomenuti da smo tri stećka, iako po katastru pripadaju Malom Ograđeniku, pribrojali ovoj nekropoli iz razloga što su evidentirani na zemljišnoj čestici istoga naziva kao stećci koji pripadaju Čerinu ("Steljci") te se nalaze u njihovoj blizini. http://www.katastar.ba/geoportal/preglednik/ (29. 3. 2018.).

$30 \mathrm{O}$ značenju astralnih motiva na stećcima više u: Krešımir Kužıć, "Kamik i zvijezde", u: Jasminka PoklečKi Stošić (ur.), Stećci. Katalog izložbe, Zagreb, 4. rujna 2008. - 2. studenoga 2008., Galerija Klovićevi dvori, Zagreb, 2008., str. 130-136.

31 Zemljišna parcela na kojoj se nalazi ovaj stećak u katastru također zove se "Groblje". http://www.katastar.ba/geoportal/preglednik/ (24. 3. 2018.).

32 R. Jolić, "Groblja u čerinskoj župi", str. 184. 
U Čitluku stećke nalazimo na pet lokaliteta. Na lokalitetu "Luka"33 u čitlučkom polju nalaze se dva stećka u obliku sljemenjaka koji su orijentirani u smjeru z-i. Nekropolu su opisali M. Vego, Š. Bešlagić, N. Miletić te R. Jolić koji točno navodi kako su danas sljemenjaci vrlo zapušteni, i ako su imali ukrase, oni su izblijedjeli. ${ }^{34}$ Stećci su postavljeni u smjeru z-i.

Na lokalitetu "Podadvor", kod rimokatoličkoga groblja, Bešlagić je zabilježio skupinu od 12 stećaka (11 ploča i 1 sljemenjak), koji su dobro obrađeni i očuvani, orijentirani u smjeru z-i, te su ukrašena 4 stećka (1 ploča, 2 sanduka i 1 sljemenjak), i to s motivima tordirane trake, bordure od povijene lozice s trolistovima ili s kosim crticama, štitom s mačem, mladim mjesecom, rozetom te kukastim križem. ${ }^{35}$ S druge strane, Arheološki leksikon Bosne i Hercegovine na ovom lokalitetu navodi 11 stećaka te mnogo manje ukrasa na njima, dok mnogo sažetiji opis ove nekropole donosi M. Vego. ${ }^{36} \mathrm{U}$ novije vrijeme R. Jolić na ovoj nekropoli nalazi i opisuje 11 stećaka u obliku ploča, sanduka i sarkofaga, te navodi da je dvanaesti stećak bio veliki sanduk koji je 1925. godine ugrađen u zid franjevačke rezidencije u Čitluku. ${ }^{37}$ Provjerom lokaliteta ustvrđeno je da se na zemljišnoj čestici koja nosi naziv "Stećki"38 nalazi ova nekropola s ukupno 11 stećaka (1 sljemenjak, 6 sanduka, 2 ploče i 2 stećka amorfnoga oblika). Spomenici su orijentirani u smjeru z-i. Ukrašena su tri stećka. Jedan sljemenjak uokviren je tordiranom trakom, a na zapadnoj strani nalazi se mač sa štitom; jedan stećak u obliku ploče uokviren je trakicom, a na stećku se nalazi motiv mača sa štitom; na jednome sanduku nalazi se motiv kukastoga križa.

33 Zemljišna čestica na kojoj se nalaze stećci u katastru naziva se "Luka". http:// www.katastar.ba/geoportal/preglednik/ (29. 3. 2018.).

34 Dok M. Vego ne iznosi ime ovoga lokaliteta, u ostaloj literaturi navodi se pod imenom "Luke". Također, ukrase (tordirana traka) spominju Bešlagić i Miletić, dok Vego i Jolić navode da na stećcima nema ukrasnih motiva. Usp. Š. BEŠLAGIĆ, Stećci. Kataloško-topografski pregled, str. 316; Arheološki leksikon Bosne i Hercegovine, sv. III., str. 302; M. VEGo, Historija Brotnja od najstarijih vremena do 1878. godine, str. 33; R. Jolıć, Župa Krista Kralja u Čitluku, str. 58-59.

35 Š. BeŠLAGIĆ, Stećci. Kataloško-topografski pregled, str. 316.

36 Arheološki leksikon Bosne i Hercegovine, sv. III., str. 304; M. Vego, Historija Brotnja od najstarijih vremena do 1878. godine, str. 37.

37 R. Jolić, Župa Krista Kralja u Čitluku, str. 56.

38 Naziv "Podadvor" nosi zemljišna čestica na kojoj se nalazi rimokatoličko groblje u Čitluku. Usp. http://www.katastar.ba/geoportal/preglednik/ (24. 3. 2018.). 


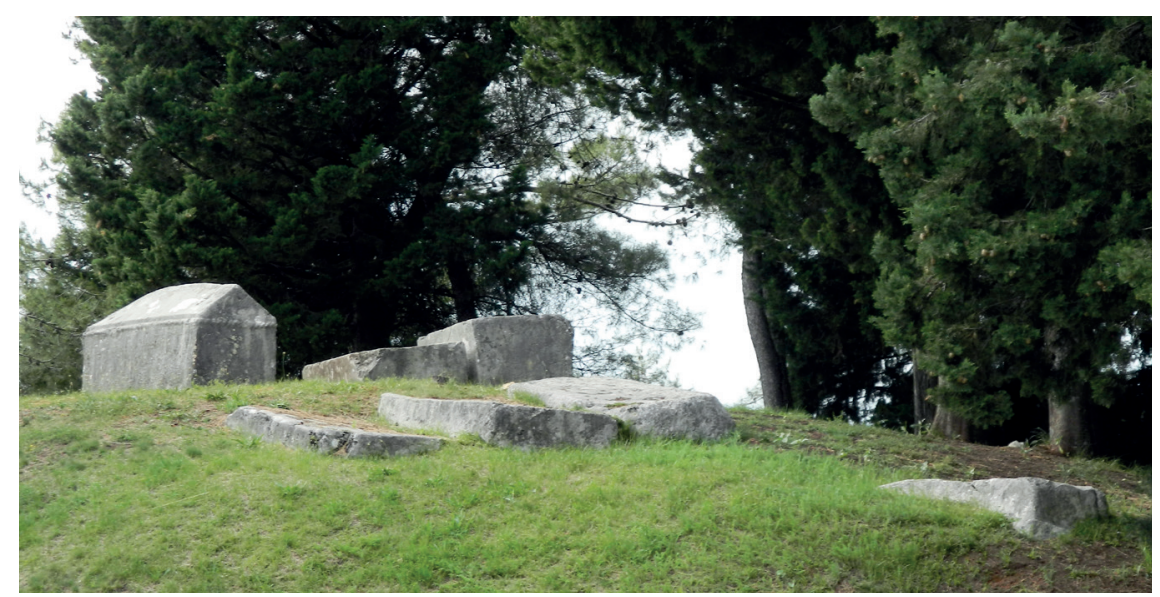

Lokalitet "Stećki" (Podadvor) u Čitluku (foto: D. Korać)

"Stećak na brijegu Tadije Primorca", kako glasi njegovo ime u literaturi, detaljno su opisali i njegovu ljepotu prepoznali M. Vego i R. Jolić, dok ovaj stećak ne spominje Bešlagić kao ni Arheološki leksikon Bosne i Hercegovine. ${ }^{39}$ Ovaj se stećak nalazi pokraj glavnoga puta koji vodi prema Mostaru, a radi se o velikoj ploči na kojoj su ukrasi odlično očuvani (bordura od vinove loze s trolistovima koja uokviruje gornju plohu stećka i dijeli ga na dvije polovine, te motiv mača sa štitom i mladoga mjeseca).

Lokalitet koji se nalazi u čitlučkom polju na zemljišnoj čestici s nazivom "Stećki", ${ }^{40}$ evidentiran je u djelu Š. Bešlagića te u Arheološkome leksikonu Bosne i Hercegovine pod nazivom "Šolini stećci", dok ga kod M. Vege i R. Jolića nalazimo pod nazivom "Dugandžića stećci". Bešlagić je na ovoj nekropoli naveo 58 stećaka u obliku sanduka, $\mathrm{N}$. Miletić je u Arheološkome leksikonu Bosne i Hercegovine zabilježila 55, Vego 36, a Jolić oko 55 stećaka. Prema autorima, spomenici su jednostavnije obrade, bez ukrasa i oštećeni, a postavljeni su u smjeru $\mathrm{z}$-i. ${ }^{41}$ Pregledom terena potvrđeno je loše stanje nekropole, a eviden-

39 M. Vego, Historija Brotnja od najstarijih vremena do 1878. godine, str. 148; R. Jolıć, Župa Krista Kralja u Čitluku, str. 59-60. I ova zemljišna parcela kao i mnoge druge dobila je ime po stećku ("Vrta kod stećka"). http://www.katastar. ba/geoportal/preglednik/ (24. 3. 2018.).

40 http://www.katastar.ba/geoportal/preglednik/ (24. 3. 2018.).

41 Usp. Š. BeŠLAGIĆ, Stećci. Kataloško-topografski pregled, str. 316; M. VEGO, Historija Brotnja od najstarijih vremena do 1878. godine, str. 148; Arheološki 
tirano je 58 stećaka od čega 5 ploča, 20 sanduka, 8 amorfnih stećaka, 19 stećaka utonulih u zemlju, a 6 stećaka je nepristupačno. Jedan stećak koji je utonuo u zemlju ukrašen je motivom križa. Jedan broj stećaka orijentiran je u smjeru j-s, a drugi u smjeru z-i.

Sljedeći lokalitet evidentirali smo pod nazivom "Brig",42 a nalazi se na brijegu iznad ulice "Popovići". Po svemu sudeći radi se o lokalitetu koji su Š. Bešlagić i N. Miletić (Arheološki leksikon Bosne $i$ Hercegovine) evidentirali pod nazivom "Krvavci" gdje se navodi 6 dobro obrađenih stećaka. ${ }^{43}$ Uvidom na terenu evidentirali smo nekropolu s oko 6 stećaka. Na žalost, nekropola je zarasla u gusto raslinje, zbog čega nismo mogli doći do svakoga stećka, a moguće je da na njoj ima još stećaka.

U Dobrome Selu stećke nalazimo na jednome lokalitetu, i to u rimokatoličkome groblju. Naime, ovu su nekropolu evidentirali već Š. Bešlagić, N. Miletić (Arheološki leksikon Bosne i Hercegovine) i M. Vego. Prema Bešlagiću ovdje se nalaze 24 stećka (22 ploče, 1 sljemenjak i 1 križ), srednje obrade, orijentirani z-i u nizovima, a ukrašena su 3 stećka (dvije ploče i jedan sljemenjak), i to motivima tordirane vrpce i križa. Miletić je evidentirala 20 stećaka, dok Vego na ovoj nekropoli navodi 14 stećaka u obliku ploča i jedan manji sljemenjak (ukupno 15 stećaka) s pretpostavkom da postoji još stećaka utonulih u zemlju. ${ }^{44}$ Obilaskom nekropole zabilježili smo 19 stećaka, a gotovo svi su utonuli u zemlju. Na ovoj nekropoli posebno se ističu plastično obrađeni ukrasi (4 stećka). Stećci su orijentirani u smjeru z-i. Na jed-

leksikon Bosne i Hercegovine, sv. III., str. 305-306; R. Jolıć, Župa Krista Kralja $u$ Čitluku, str. 58. Jolić ovaj lokalitet vodi pod nazivom "Dugandžića stećci (Ćemalovac)", a za lokalitet "Šolini stećci" navodi da ne postoji. Usp. R. Jolić, Župa Krista Kralja u Čitluku, str. 59, bilješka 64.

42 http://www.katastar.ba/geoportal/preglednik/ (24. 3. 2018.).

43 Š. BešLAGić, Stećci. Kataloško-topografski pregled, str. 316; Arheološki leksikon Bosne i Hercegovine, sv. III., str. 301. Vjerojatno zbog Bešlagićeve pogrješne ubikacije ovoga lokaliteta R. Jolić zaključio je da ova nekropola ne postoji. R. Jolić, Župa Krista Kralja u Čitluku, str. 59, bilješka 64.

44 Š. BešLAGić, Stećci. Kataloško-topografski pregled, str. 316; Arheološki leksikon Bosne i Hercegovine, sv. III., str. 293; M. VEGo, Historija Brotnja od najstarijih vremena do 1878. godine, str. 149. M. Vego je u Dobrom Selu naveo i jedan stećak u podu prostorije nekadašnjega zadružnoga doma, koja je danas renovirana i nema tragova postojanja stećaka, a Vegin podatak o ovome stećku nije poznat mještanima s kojima smo razgovarali. Usp. M. Vego, Historija Brotnja od najstarijih vremena do 1878. godine, str. 149 . 
nome stećku koji je utonuo u zemlju gornja ploha ukrašena je motivima grčkoga križa, pješčanoga sata (?), križa uokvirenoga tordiranom trakom i polumjesecom; također na drugome stećku utonulome u zemlju nalazimo motiv križa te jelena; jedan stećak koji je utonuo u zemlju bogato je ukrašen motivima križa s rozetama a jedan sljemenjak ukrašen je tordiranom trakom.

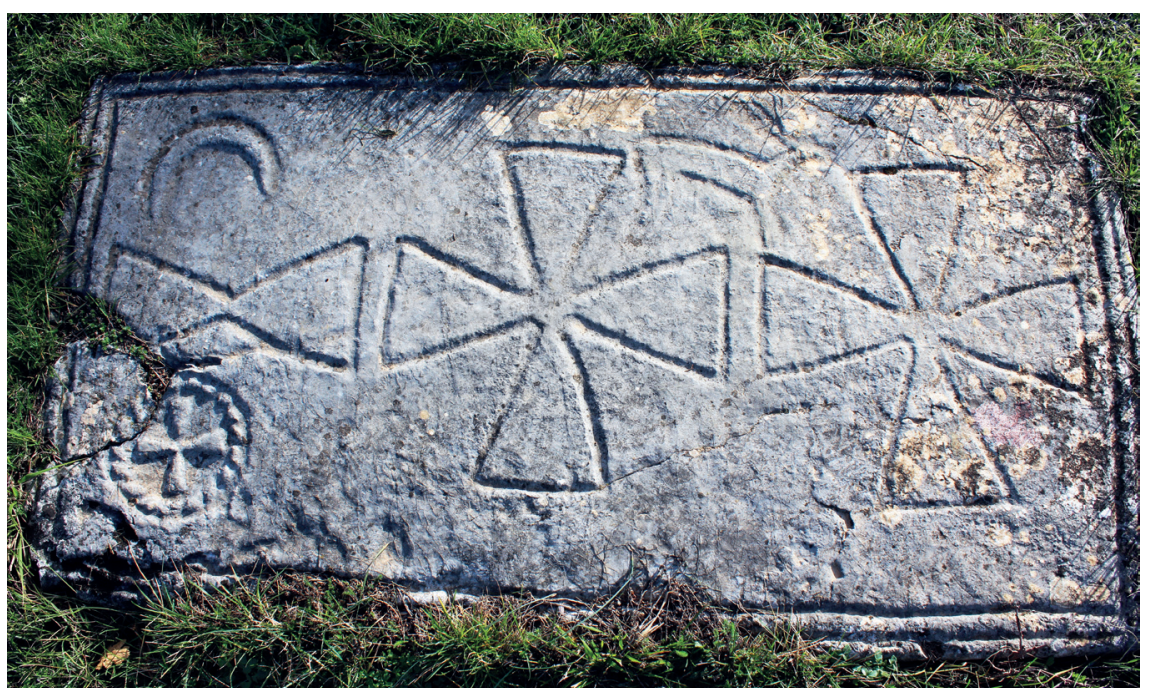

Ukrasni motivi na stećku u Dobrom Selu (foto: R. Mirković)

U selu Dragićina stećke nalazimo na tri lokaliteta. Na lokalitetu koji je u dosadašnjoj literaturi (Arheološki leksikon Bosne i Hercegovine) nazvan "Dragićina" evidentirano je 6 stećaka u obliku sanduka. ${ }^{45}$ Lokalitet se nalazi pokraj glavnoga puta koji vodi prema Čitluku. ${ }^{46}$ Uvidom na lokalitetu potvrđeno je 6 sanduka, koji su dobro očuvani i nemaju ukrasa. Njihova orijentacija je u smjeru z-i.

Drugi lokalitet s nazivom "Grab", ${ }^{77}$ nalazi se pokraj ceste za Čerin, gdje je Bešlagić naveo 10 stećaka u obliku sanduka, a isti podatak o broju stećaka nalazimo i u Arheološkom leksikonu Bosne i Hercegovine. Dok

45 Arheološki leksikon Bosne i Hercegovine, sv. III., str. 293.

46 Prema katastru stećci se nalaze na parceli "Bašća". Usp. http://www.katastar. ba/geoportal/preglednik/ (22. 3. 2018.).

47 Katastarskom provjerom potvrđeno je da se ovaj lokalitet naziva "Grab". http://www.katastar.ba/geoportal/preglednik/ (24. 3. 2018.). 
Bešlagić navodi kako je orijentacija stećaka na ovoj nekropoli različita i nesigurna, prema Arheološkom leksikonu Bosne i Hercegovine stećci su orijentirani u smjeru z-i. ${ }^{48}$ Uvidom na lokalitetu zabilježeno je 14 stećaka, od čega sa sigurnošću možemo razlikovati jednu ploču i 5 sanduka, 2 su amorfna, a ostali stećci utonuli su u zemlju ili obrasli raslinjem. Ukrašena su samo 2 stećka. Na jednome sanduku nalazi se motiv križa na postolju a na drugome stećku također u obliku sanduka ukrašena je gornja ploha s tri kamenice postavljene vodoravno jedna pokraj druge. Stećci su orijentirani u smjeru z-i.

Na lokalitetu "Stojića groblje" u Dragićini, prema Š. Bešlagiću i N. Miletić (Arheološki leksikon Bosne i Hercegovine) nalazi se 18 stećaka (17 sanduka i 1 ploča). ${ }^{49}$ Spomenici su raspoređeni u groblju i pokraj njega ${ }^{50}$ i dobro su obrađeni. M. Vego je u groblju zabilježio 3 stećka (plo-

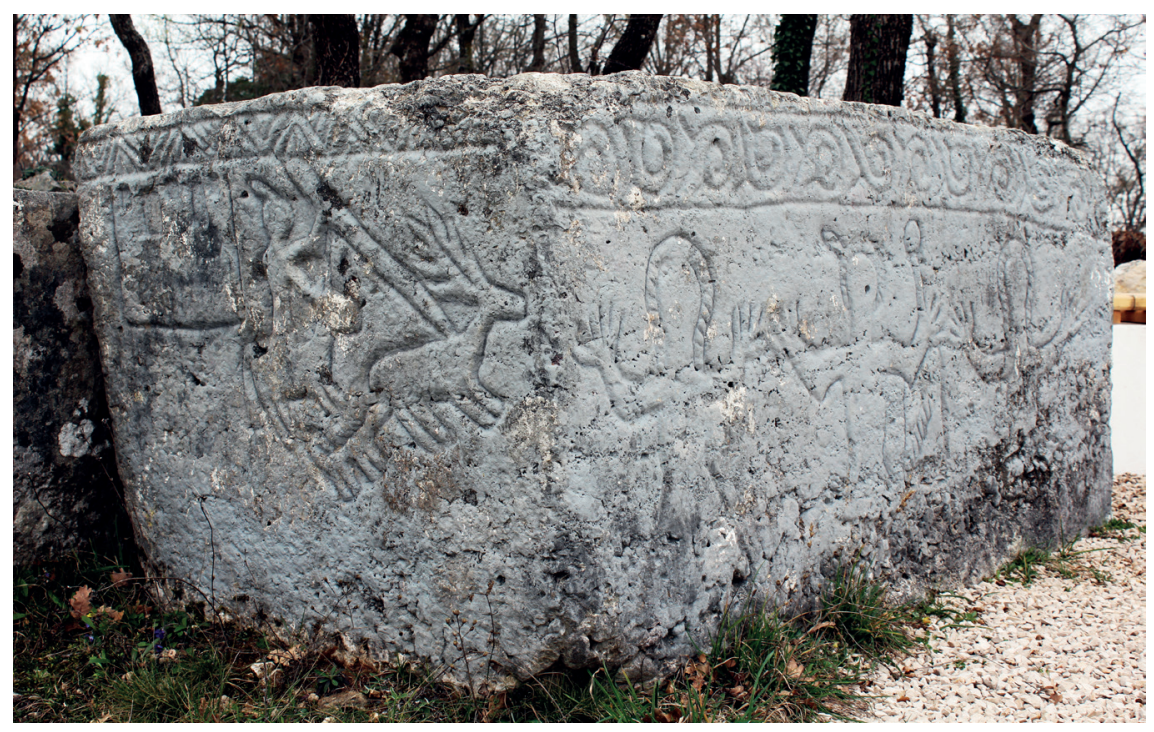

Ukrasni motivi na stećku pokraj "Stojića groblja" u Dragićini (foto: R. Mirković)

48 Š. BEŠLAGIĆ, Stećci. Kataloško-topografski pregled, str. 315; Arheološki leksikon Bosne i Hercegovine, sv. III., str. 296.

49 Š. BeŠLAgIć, Stećci. Kataloško-topografski pregled, str. 314; Arheološki leksikon Bosne i Hercegovine, sv. III., str. 306.

50 Lokalitet se nalazi pokraj glavnoga puta koji vodi u Čitluk, a katastarske čestice na kojima se nalaze stećci zovu se "Čuske" i "Arinovica". http://www.katastar.ba/geoportal/preglednik/ (22. 3. 2018.). 
če), a izvan groblja 9 stećaka u obliku sanduka i ploče. Osim toga, Vego spominje i jedan sljemenjak koji se nalazio na granici između Čerina i Dragićine a koji je prenesen u vrt Zemaljskoga muzeja u Sarajevu. ${ }^{51} \mathrm{Te}-$ renskim istraživanjem potvrđeno je kako se na ovome lokalitetu nalazi 18 stećaka od čega sa sigurnošću možemo razlikovati 5 u obliku ploče i 8 sanduka. U katoličkom groblju nalazi se 6, a izvan groblja 12 stećaka. Stećci su orijentirani u smjeru z-i, a samo četiri stećka u smjeru j-s. Motivi i predstave zaista su visoke umjetničke obrade. Valja spomenuti da je jedan stećak ugrađen u zid groblja, a na jednoj manjoj ploči koja se nalazi blizu kapelice uočljiv je prikaz muške figure. Izvan groblja ukrašena su četiri stećka. Gornja ploha jednoga stećka u obliku sanduka podijeljena je krakovima križa na četiri kvadrata, gdje nalazimo i motiv rozete dok je jedna duža strana stećka ukrašena scenom lova na jelena, a jedna kraća strana motivom jelena. Na drugome sanduku gornja ploha ukrašena je tordiranom trakom s voluticama, sjeverna strana ukrašena je prikazom lova na jelena, a u pozadini se vidi arhitektura (dvorac), dok se na dužoj (zapadnoj) strani ovoga stećka vidi prikaz muškarca s mačem između dvije žene koje drže visoko podignute ruke. Na stećku u obliku ploče gornja ploha ukrašena je mačem sa štitom, a na drugome stećku u obliku ploče nalazi se kamenica.

U Gradnićima je Bešlagić evidentirao samo stećak s natpisom (u dvorištu osnovne škole), a u Arheološkome leksikonu Bosne i Hercegovine, osim ovoga stećka, navodi se još jedan lokalitet "Ivan polje", gdje N. Miletić evidentira 3 stećka, i to u obliku sanduka i križa, a od ukrasa navodi predstavu jelena. ${ }^{52}$ Prije desetak godina popis stećaka na području Gradnića dopunio je I. Dugandžić, a u novije vrijeme sve te lokalitete također je obišao i opisao R. Jolić, pa danas možemo govoriti o četiri lokaliteta na ovome području, na kojima ima ukupno 9 stećaka. ${ }^{53}$ Prvi, svakako najzanimljiviji lokalitet jest onaj

51 M. Vego, Historija Brotnja od najstarijih vremena do 1878. godine, str. 149.

52 Š. BeŠLAGić, Stećci. Kataloško-topografski pregled, str. 316; Arheološki leksikon Bosne i Hercegovine, sv. III., str. 306.

53 I. Dugandžić, "Nekropole stećaka u župi Gradnići", str. 232-233; R. Jolić, Župa Brotnjo - Gradnići, str. 41. Svakako treba napomenuti da je na stećke na području Ivan polja (lokalitete navodi kao Doci i Ivin brijeg) te Popratima već ranije upozorio M. Vego, ne dajući detaljnije opise, a za dva stećka u Popratima navodi kako nemaju veće važnosti. Zanimljivim se čini Vegina pretpostavka da je naziv Ivan polje možda u svezi s pisarom Ivanom koji se spominje na stećku ispred osnovne škole u Gradnićima. Usp. M. VEGo, Historija Brotnja od najstarijih vremena do 1878. godine, str. 150. 


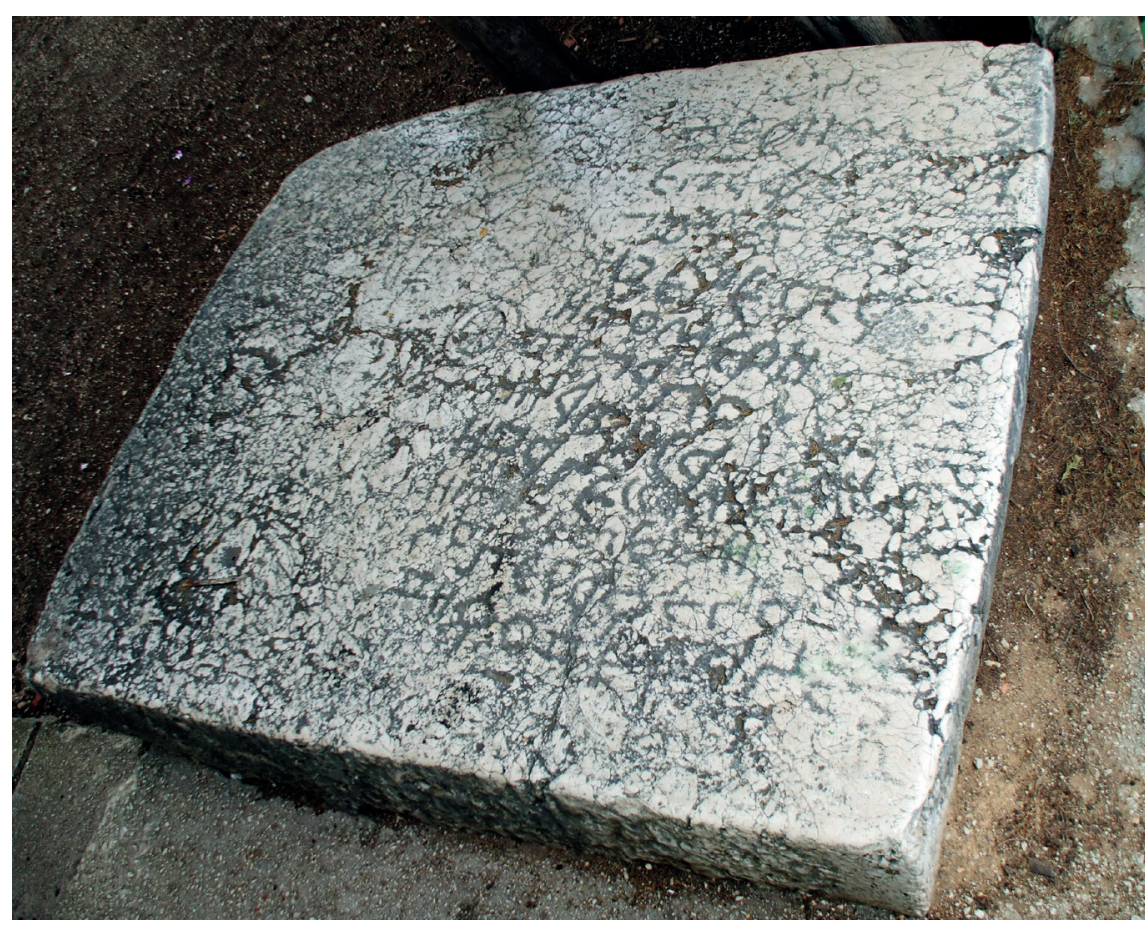

Stećak Petra Milanova u Gradnićima

(foto: D. Korać)

pokraj škole u Gradnićima gdje je evidentiran stećak s natpisom. Naime, Bešlagić navodi kako je ovaj osamljeni stećak u obliku ploče orijentiran $\mathrm{z}$-i, dobro obrađen, ukrašen motivom rozeta $\mathrm{u}$ vijencima i natpisom u kojemu se spominje Petar Milanov i pisar Ivan. ${ }^{54}$ Vego također spominje ploču ukrašenu zvijezdom "u plastičnom krugu (izbočeno)" i ćirilskim natpisom. ${ }^{55}$ Sažete podatke o ovome stećku nalazimo i u Arheološkome leksikonu Bosne i Hercegovine, a ovaj stećak opisuje i R. Jolić osvrćući se više na sam natpis, pa navodi kako je natpis urezan na površini velikoga stećka u obliku ploče i da je teško čitljiv, a od ukrasa evidentirao je jednu veliku rozetu. ${ }^{56}$ Stećak ima oblik sanduka dimenzija 236 × 200 x $45 \mathrm{~cm}$, a ukrašen je rozetom u

54 Š. BešLAgić, Stećci. Kataloško-topografski pregled, str. 316. Zanimljivo je spomenuti da je u zapadnom dijelu Hercegovine na stećcima evidentirano samo 6 pisara. O tome više u: Š. BEŠLAGIć, Stećci - kultura i umjetnost, str. 475.

55 M. Vego, Historija Brotnja od najstarijih vremena do 1878. godine, str. 150.

56 Arheološki leksikon Bosne i Hercegovine, sv. III., str. 298; R. Jolić, Župa Krista Kralja u Čitluku, str. 55. 
vijencu. Na njemu se nalazi natpis: "A se (ovdje) leži Petar' Milanov. Jeno (eno) Peri meta jegova žena (njegova) i zde (ovdje), vaj, pomenite ga (pomolite se)! Prinapisa Ivane koji jedino Pera jegovi (njegovi) ove dane (pomenuše)". ${ }^{57}$

U Ivanovu polju, u blizini kapelice sv. Ante, na zemljišnoj čestici koja se zove "Stećak"58 nalaze se 3 stećka u obliku sanduka a orijentirani su u smjeru z-i. Stećci su zarasli u grmlje, pa nije bilo moguće provjeriti imaju li ukrasa. Nedaleko od njih nalazi se još jedan stećak. Prema pisanju N. Miletić jedan je stećak ukrašen predstavom jelena, a Jolić ističe jedan bogato ukrašen stećak (gornja ploha stećka obrubljena je vinovom lozom, na stećku se nalazi i reljefni križ čiji su kraci ukrašeni, a također od ukrasa navodi i dvije rozete i dva polumjeseca koji su raspoređeni u dijagonalno suprotnim poljima). ${ }^{59}$ Sljedeći lokalitet nalazi se na području Ivanova polja na zemljišnoj čestici koja se zove "Poprati", gdje su evidentirana dva stećka. Budući da na sebi nemaju nikakvih ukrasa, Vego je već ranije naveo kako nemaju većega značaja. ${ }^{60}$ Također, u Gradnićima postoji još jedan lokalitet sa stećcima $s$ nazivom "Podvornice (Poprikuše ili Njive)" na kojemu se nalaze dva stećka (jedan u obliku sanduka a drugi amorfni). Stećci su zarasli u grmlje pa nije moguće vidjeti imaju li ukrasa. No, prema nekim navodima, jedan je stećak ukrašen rozetom i bordurom. ${ }^{61}$

U Hamzićima nalazimo više lokaliteta ali s manjim brojem nadgrobnih spomenika. Riječ je o šest lokaliteta, od kojih tri nisu bila do sada nigdje evidentirana. U dosadašnjoj literaturi neki su auto-

57 Natpis je naveden prema: M. Vego, Historija Brotnja od najstarijih vremena do 1878. godine, str. 139-140. O natpisu vidi i u: M. ŠImIć, "Natpisi na stećcima u župi Gradnići", str. 239-240; M. ŠImIĆ, Jezik srednjovjekovnih kamenih natpisa iz Hercegovine, str. 96-98; R. Jolić, Župa Krista Kralja u Čitluku, str. 55; R. Jolić, Župa Brotnjo - Gradnići, str. 41-42.

58 http://www.katastar.ba/geoportal/preglednik/ (22. 3. 2018.).

59 Arheološki leksikon Bosne i Hercegovine, sv. III., str. 306; R. Jolić, Župa Brotnjo - Gradnići, str. 42. Opis ovoga stećka ranije je donio i I. Dugandžić. I. DugandžIć, "Nekropole stećaka u župi Gradnići", str. 233.

60 Usp. M. Vego, Historija Brotnja od najstarijih vremena do 1878. godine, str. 150. Ovaj lokalitet nije naveden u Bešlagića a ni u Arheološkome leksikonu Bosne i Hercegovine. Tek ga u novije vrijeme spominje I. Dugandžić a zatim R. Jolić. I. DugAndžIć, "Nekropole stećaka u župi Gradnići", str. 233; R. Jolıć, Župa Brotnjo - Gradnići, str. 42.

61 I. Dugandžıć, "Nekropole stećaka u župi Gradnići", str. 233; R. Jolić, Župa Brotnjo - Gradnići, str. 42. 
ri tri lokaliteta, vjerojatno zbog njihove male udaljenosti, navodili kao jednu nekropolu s nazivom "Kripovac". Tako je Š. Bešlagić na ovim lokalitetima zabilježio 9 stećaka (jedna ploča i 8 sanduka) dobre obrade, a posebnu pozornost posvetio je najbogatije ukrašenom sanduku od kojega je napravljeno korito. Stećak dimenzija 210 x 160 $\mathrm{x} 46 \mathrm{~cm}$ postavljen je u smjeru z-i. Kao najveću vrijednost Bešlagić izdvaja reljefne ukrase koji se nalaze na "ivičnoj vodoravnoj površini i na tri njegove vertikalne strane". Od ukrasa pojavljuju se bordura od niza spiralica, kolo sa šest figura, scena lova na jelena, scena ratnika s topuzom i 3 stojeće figure, a iza figura silueta utvrđenoga grada. Također, javljaju se i motivi rozete, mladi mjesec i predstave jelena. ${ }^{62}$ $\mathrm{S}$ druge strane, $\mathrm{u}$ Arheološkome leksikonu Bosne i Hercegovine nalaze se tri lokaliteta, gdje se navodi kako se na srednjovjekovnome groblju u Hamzićima nalazi 5 stećaka u obliku ploče i sanduka, orijentacije z-i, te s ukrasima bordura i simboličnih znakova. Kao drugi lokalitet naveden je "Kripovac" u kojemu je jedan osamljeni stećak (ploča) u sekundarnome položaju (ukras: arhitektonski motiv, bordura i figuralne scene), a kao treći lokalitet "Stećci" na kojemu su četiri stećka u obliku visokih sanduka orijentacija $\mathrm{z}$-i, a od ukrasa navodi se predstava jelena. ${ }^{63} \mathrm{O}$ lokalitetu "Kripovac" pisao je i M. Vego. ${ }^{64}$

Kako je spomenuto, osim ovoga bogato ukrašenoga stećka na "Kripovcu", u blizini se nalazi još nekoliko stećaka koje smo zbog jasnoće odlučili evidentirati zasebno. Naime, pregledom terena na brežuljku u blizini "Kripovca" na zemljišnim česticama koje nose naziv "Podkripovac" i "Harem"65 potvrđena je skupina od četiri sanduka, od kojih je jedan ukrašen motivom plastično obrađenoga jelena. Stećci su dobro očuvani i postavljeni u smjeru z-i.

Istočno od "Kripovca", a u njegovoj neposrednoj blizini, na zemljišnoj čestici s nazivom "Vakup"66 nalaze se dva uspravljena stećka ukraše-

62 Zbog dimenzija i oblika korita, Bešlagić objašnjava kako nije isklesano iz stećka nego napravljeno upravo za ovu namjenu, a prema reljefnim motivima smatra kako je nastalo u razdoblju između 14. i 15. stoljeća. Š. BEŠLAGIĆ, Stećci. Kataloško-topografski pregled, str. 314. Detaljan opis vidi u: ŠEFIK BEŠLAGIĆ, "Korito čatrnje u Hamzićima", u: Brotnjo, Zbornik, 3, Matica hrvatska Čitluk, Čitluk, 2006., str. 50-57.

63 Arheološki leksikon Bosne i Hercegovine, sv. III., str. 299, 301, 306.

64 M. Vego, Historija Brotnja od najstarijih vremena do 1878. godine, str. 150-151.

65 http://www.katastar.ba/geoportal/preglednik/ (22. 3. 2018.).

66 Navedeno prema: http://www.katastar.ba/geoportal/preglednik/ (22. 3. 2018.). 


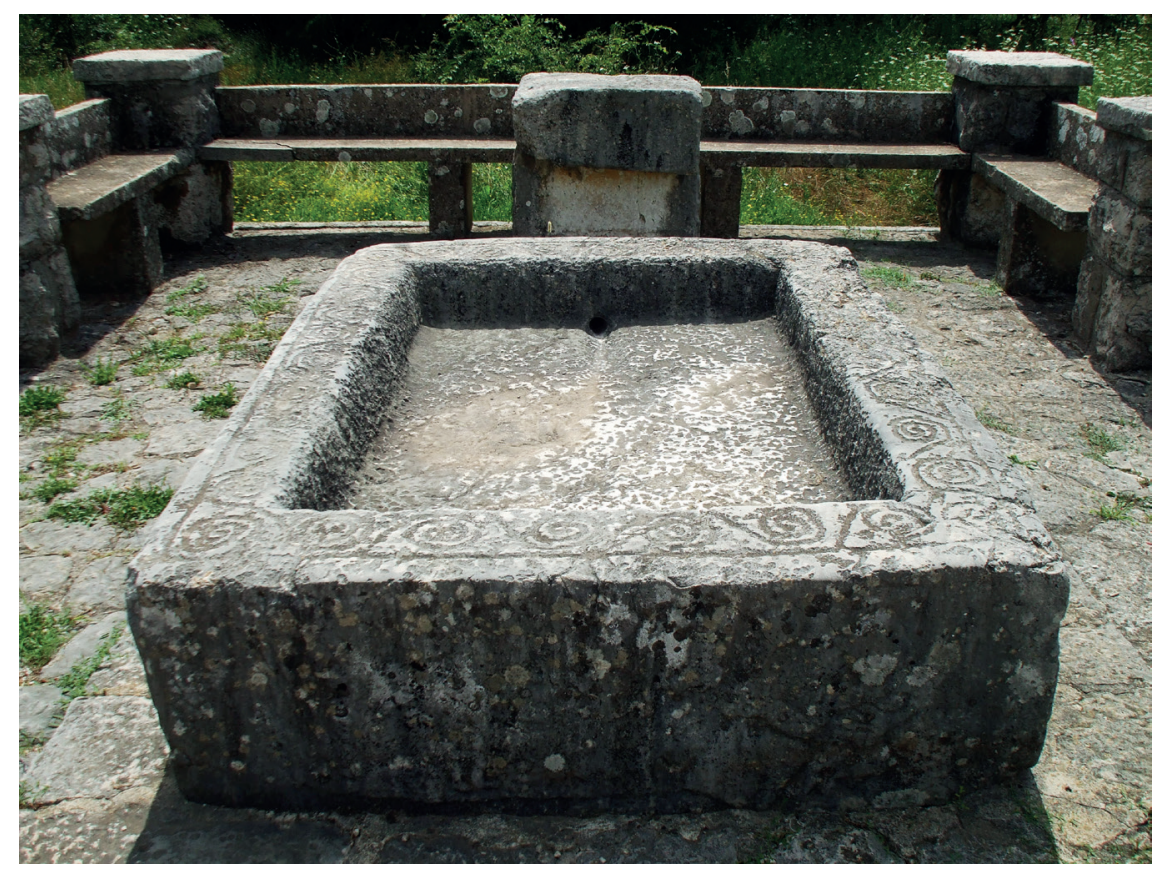

"Kripovac" u Hamzićima (foto: D. Korać)

na rozeticama, a riječ je o dvije dobro očuvane ploče koje su najvjerojatnije prvobitno bile položene.

Sjeverno od "Kripovca" na lokalitetu "Latica", ${ }^{67}$ iznad naselja, nalazi se stećak koji nije do sada nigdje evidentiran. Radi se o jednom sanduku bez ukrasa, oštećenom s jedne strane, koji, kako se stječe dojam, nije bio do kraja završen. Pretpostavljamo, s obzirom na teren gdje se nalazi, da je ovaj stećak ovdje klesan i tu ostao.

U Hamzićima (Donjim) nalazi se lokalitet sa stećcima, do sada neevidentiran u literaturi, a riječ je o zemljišnim česticama koje se u katastru nazivaju "Steljak". ${ }^{68} \mathrm{Na}$ jednoj od njih nalazi se osamljen stećak u obliku sanduka (dimenzija 220 x 120 x $45 \mathrm{~cm}$ ), bez ukrasa, orijentiran u smjeru z-i. Nedaleko od njega na drugoj čestici istoga imena nalaze se dva stećka (najvjerojatnije sanduka), zarasla u grmlje i prekrivena zemljom i gustim raslinjem tako da nije bilo moguće uzeti dimenzije i vidjeti imaju li ukrasa.

67 Navedeno prema: http://www.katastar.ba/geoportal/preglednik/ (22. 3. 2018.). 68 http://www.katastar.ba/geoportal/preglednik/ (22. 3. 2018.). 
Posljednji lokalitet, koji je pronađen na području ovoga naselja nalazi se zapravo u polju na zemljišnoj čestici s nazivom "Stupi"69 gdje su evidentirana 4 stećka (3 sanduka i jedna ploča). Tri sanduka su jedan do drugoga od kojih je jedan potpuno nepristupačan. Svi su ovi stećci u vrlo lošem stanju i nije moguće vidjeti imaju li ukrasa. Od njih se izdvaja svakako stećak u obliku ploče, koji je udaljen nekoliko metara od tri navedena stećka, a na sebi ima dvije jednostavne trake, te je vrlo vjerojatno da još ima nekih ukrasa, koji zbog stanja stećka nisu vidljivi. Stećci su orijentirani u smjeru z-i.

U Krehinu Gracu nalazimo četiri lokaliteta sa stećcima. Naime, Š. Bešlagić je na granici između Vionice i Krehina Graca zabilježio nekropolu s nazivom "Barovina ili Vinogradi" na kojoj bilježi 24 stećka od čega 23 sanduka i jedan sljemenjak, orijentiranih u smjeru z-i, a ukrašena su dva sanduka s ukrasnim motivima križa i pravokutnoga udubljenja. ${ }^{70}$ Isti broj stećaka navodi i Jolić, napominjući kako su spomenici dobro očuvani i dobre obrade, 2 sanduka ukrašena su motivom križa i "pravokutnog udubljenja", za koje smatra da je novijega datuma i da je najvjerojatnije služilo kao pojilište za stoku. Spomenici su orijentirani u smjeru z-i. ${ }^{71} \mathrm{~S}$ druge strane, N. Miletić u Arheološkome leksikonu Bosne i Hercegovine, pozivajući se na Š. Bešlagića, ovaj lokalitet vodi pod drugim nazivom i donosi malo drugačije podatke. Lokalitet je naveden kao "Jakerovac (Ploče, Vinogradi) Vionica", a tu se navodi da se na srednjovjekovnoj nekropoli nalazi 25 stećaka u obliku ploča, sanduka i sarkofaga, orijentiranih z-i, a od ukrasa navode se simbolični znaci. ${ }^{72}$ Slične podatke o ovome lokalitetu donosi i M. Vego ali ga vodi pod drugim imenom ('Stećci' kod Jakerovca"), gdje također navodi 24 stećka u obliku ploča i sanduka a sudeći prema njegovu opisu riječ je o ovom istom lokalitetu. ${ }^{73}$ Terenskim istraživanjem ova nekropola evidentirana je na zemljišnoj čestici s nazivom "Ploče", ${ }^{74}$ a nalazi se kod "Jakerovca". Na ovoj nekropoli evidentirali smo 25 stećaka, od čega 11 sanduka, 4 sljemenjaka, 1 u sekundarnoj uporabi kao korito, 2 stećka amorfnoga

69 http://www.katastar.ba/geoportal/preglednik/ (22. 3. 2018.).

70 Š. BešLAGIĆ, Stećci. Kataloško-topografski pregled, str. 317.

71 R. Jolıć, Župa Krista Kralja u Čitluku, str. 62-63.

72 Arheološki leksikon Bosne i Hercegovine, sv. III., str. 299.

73 M. Vego, Historija Brotnja od najstarijih vremena do 1878. godine, str. 151.

74 http://www.katastar.ba/geoportal/preglednik/ (22. 3. 2018.). 
oblika dok je 7 stećaka utonulo u zemlju. Prilikom izgradnje puta stećci su pomaknuti s prvobitnoga položaja, a nekropola je danas u vrlo zapuštenom stanju. Ukrašena su dva stećka i to motivom križa. Naime, gornja ploha jednoga sanduka romboidnoga oblika ukrašena je motivom križa, a na jednome prevrnutom sljemenjaku nalazi se također motiv križa. Stećci su postavljeni u smjeru z-i.

Drugi lokalitet u Krehinu Gracu zove se "Dračevica", 75 a nekropola s ovim nazivom evidentirana je u Arheološkom leksikonu Bosne i Hercegovine gdje je zabilježeno 14 stećaka (ploče, sarkofag i križ) orijentiranih u smjeru z-i, a od ukrasa navodi se tordirana traka, simbolični znaci i jelen. ${ }^{76}$ Š. Bešlagić i $M$. Vego u svome izvješću o ovome lokalitetu nisu spomenuli naziv nekropole, navodeći samo da se nalazi blizu groblja. Bešlagić je na ovoj nekropoli evidentirao skupinu od 11 stećaka u obliku sanduka te jedan stećak u obliku križa. Prema Vegi, na nekropoli se nalazilo 10 stećaka, te još jedan stećak koji je prenesen u Zemaljski muzej u Sarajevo. ${ }^{77}$ Uvidom na lokalitetu evidentirali smo 11 stećaka i to jednu ploču, 8 sanduka, jedan stećak ugrađen u zid, a jedan je stećak utonuo u zemlju. Stećci su postavljeni u smjeru z-i. Ukrašena su 3 stećka na kojima se pojavljuju motivi: tordirana trakica s cik-cak linijama, savijene volute, kamenica, križ, rozeta, mladi mjesec, pas i čovjek s mačem i štitom. Naime, na gornjoj plohi jednoga sanduka nalazi se motiv čovjeka s mačem i štitom koji je okružen tordiranom trakicom cik-cak linijama, a na zapadnoj i istočnoj strani nalaze se po dvije sastavljene volute. $\mathrm{Na}$ drugome sanduku nalazi se motiv uklesane kamenice, te polumjesec i rozeta. Na trećemu stećku u obliku ploče nalazi se veliki križ (obrubljen je trakom) koji dijeli gornju plohu na četiri polja, a na stećku se nalaze i motivi rozete, mladoga mjeseca i životinje (pas). Spomenici su postavljeni u smjeru z-i.

Treći lokalitet u Krehinu Gracu, koji se ne spominje u dosadašnjoj literaturi, evidentirali smo pod nazivom "Grebina". ${ }^{78}$ Smješten je na

75 http://www.katastar.ba/geoportal/preglednik/ (22. 3. 2018.).

76 Arheološki leksikon Bosne i Hercegovine, sv. III., str. 293.

77 Š. BEŠLAGIĆ, Stećci. Kataloško-topografski pregled, str. 317; M. VEGO, Historija Brotnja od najstarijih vremena do 1878. godine, str. 151-152. Opis stećka koji se nalazi u Zemaljskom muzeju u Sarajevu, a za kojega Vego pretpostavlja da bi mogao pripadati jednom članu obitelji Milatović, vidi u: M. VEGO, Historija Brotnja od najstarijih vremena do 1878. godine, str. 152.

78 Navedeno prema: http://www.katastar.ba/geoportal/preglednik/ (23. 3. 2018.). 


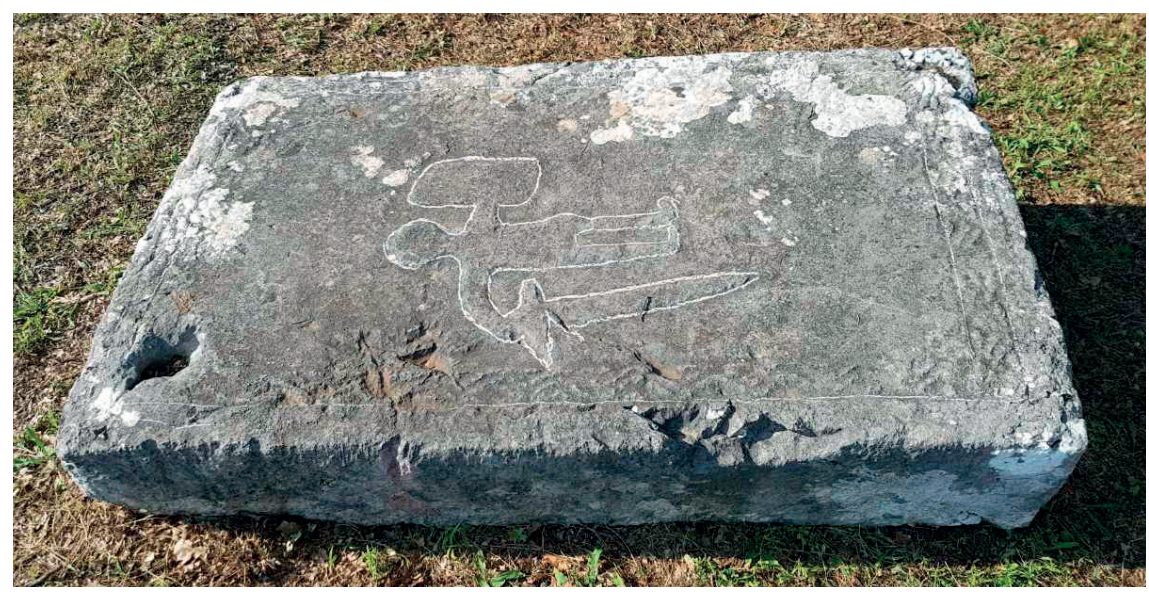

Stećak na lokalitetu "Dračevica" u Krehinu Gracu

(foto: D. Korać)

malom uzvišenju pokraj puta gdje se nalaze 3 neukrašena stećka (jedna ploča i 2 sanduka), a u njihovoj blizini nalazi se još jedan stećak u obliku sanduka, i to pokraj kuće obitelji Lovrić.

Posljednji lokalitet u ovome naselju nosi naziv "Grudina".79 Ovu je nekropolu pod nazivom "Grudine" Bešlagić naveo uz Čitluk gdje je pobrojao ukupno 95 stećaka (92 sanduka i 3 sljemenjaka) nejednake obrade, od kojih su četiri ukrašena (3 sanduka i 1 sljemenjak), a među stećcima ima i antičkih spolija. S druge strane, M. Vego je na ovome lokalitetu ("Marića ogradi", kako navodi) zabilježio oko 100 stećaka raznih oblika. ${ }^{80}$ Lokalitet je veoma zarastao u trnje i visoko raslinje, zbog čega je bilo onemogućeno mjerenje stećaka. Zabilježili smo 118 stećaka ali taj broj zasigurno nije potpun.

79 Navedeno prema: http://www.katastar.ba/geoportal/preglednik/ (23. 3. 2018.).

80 Š. BEŠLAgIć, Stećci. Kataloško-topografski pregled, str. 316; M. VEGo, Historija Brotnja od najstarijih vremena do 1878. godine, str. 151. Bešlagić je ovu nekropolu pogrješno locirao i pribrojio Čitluku, navodeći kako se ova nekropola nalazi 500 metara zapadno od naselja, a ovaj lokalitet smješten je na granici Vionice i Krehina Graca. Vjerojatno zbog njegove pogrješne ubikacije ovoga lokaliteta, Jolić je naveo kako ova nekropola ne postoji. R. Jolıć, Župa Krista Kralja u Čitluku, str. 59, bilješka 64. Spomenimo i da se u Arheološkome leksikonu Bosne i Hercegovine uz lokalitet s ovim nazivom ne nalaze podatci o ovim srednjovjekovnim spomenicima. Naime, I. Marijanović navodi da se na Grudini u Krehinu Gracu nalazi rimsko naselje i ostatci temelja zgrada, fragmenata cigli i arhitektonskog ukrasa od značajnije rimske zgrade, a također spominje i begovsku kulu (Krehin Dvor). Usp. Arheološki leksikon Bosne i Hercegovine, sv. III., str. 299. 
U selu Krućevići nalazi se lokalitet sa stećcima koji je već ranije u Arheološkome leksikonu Bosne i Hercegovine evidentirala N. Miletić, navodeći kako se uz muslimansko groblje nalazi 7 stećaka u obliku ploče koji se nalaze u smjeru s-j, a od ukrasa spominje bordure. ${ }^{81}$ Stećci se nalaze na zemljišnoj čestici s nazivom "Lopata". ${ }^{82}$ Uvidom na terenu na ovom lokalitetu evidentirali smo 7 stećaka, od čega 3 ploče, 2 sanduka i 2 stećka utonula u zemlju. Dva su stećka ukrašena motivima cik-cak bordure, mjeseca i kruga.

U naselju Mali Ograđenik stećke nalazimo na tri lokaliteta, a svi su poznati iz dosadašnje literature. Naime, na katoličkom groblju s nazivom "Dugandžića groblje", Š. Bešlagić evidentirao je 4 veća sanduka, a M. Vego navodi 1 sanduk i 3 ploče. ${ }^{83} \mathrm{Na}$ lokalitetu je utvrđeno kako se na nekropoli nalaze 4 stećka od čega 1 ploča i 3 sanduka. Stećak u obliku ploče ukrašen je motivima tordirane trake $s$ trolistovima, mačem sa štitom, a rubovi su ukrašeni motivom rozetice. Stećci su orijentirani u smjeru z-i.

Sljedeći lokalitet zove se "Gradina". Bešlagić je na ovome lokalitetu, koji je smješten iznad groblja na tumulu, zabilježio nekropolu s 5 stećaka u obliku sanduka, navodeći da su postavljeni u smjeru z-i, nemaju ukrasa, a među njima su nađeni ostatci rimskoga građevinskog materijala ${ }^{84}$ Slične podatke donose Đ. Basler i N. Miletić u Arheološkome leksikonu Bosne i Hercegovine, koji kao i Bešlagić pišu da se na jednom tumulu nalazi 5 sanduka uz rimsku spoliju, ${ }^{85}$ dok Vego navodi kako se na ovome lokalitetu nalazi nekoliko razbijenih stećaka bez ukrasa. ${ }^{86}$ Uvidom na terenu mišljenja smo kako se na ovoj nekropoli ne može sa sigurnošću utvrditi jesu li antički fragmenti korišteni kao spolije za stećke, što je bila tadašnja praksa. No, ipak ćemo reći da se na nekropoli nalazi oko 10 stećaka, od čega dvije ploče, 7 sanduka, a jedan stećak utonuo je u zemlju. Stećci nemaju ukrasa. Orijentirani su uglavnom z-i.

81 Arheološki leksikon Bosne i Hercegovine, sv. III., str. 301.

82 http://www.katastar.ba/geoportal/preglednik/ (23. 3. 2018.).

83 Š. BeŠLAGić, Stećci. Kataloško-topografski pregled, str. 315; M. VEGo, Historija Brotnja od najstarijih vremena do 1878. godine, str. 154.

84 Š. BeŠLAGIĆ, Stećci. Kataloško-topografski pregled, str. 314.

85 Arheološki leksikon Bosne i Hercegovine, sv. III., str. 297.

86 M. Vego, Historija Brotnja od najstarijih vremena do 1878. godine, str. 155. 
Treći lokalitet nosi naziv "Glavica", ${ }^{87}$ a njega je ispravno evidentirala N. Miletić, dok je, kako je spomenuto, Bešlagić ovu nekropolu sjedinio zajedno s navedenom nekropolom u Čerinu. Na ovom lokalitetu Miletić je zapisala 24 stećka (ploče, sanduci, visoki sanduci i sljemenjaci), a od ukrasa: bordura, ljudska figura, štit s mačem, simbolični znaci i figuralne scene. ${ }^{88}$ Uvidom na terenu evidentirali smo 28 stećaka i još 3 fragmenta stećka. Nekropola je u vrlo lošem stanju. Što se tiče oblika, stanje je sljedeće: sanduka (15), sanduka s postoljem (2), sljemenjaka s postoljem (1), ploča (7) te amorfna (3). Ukrašeno je 9 stećaka. Naime, jedna ploča ukrašena je tordiranom trakom, te jelenom i mladim mjesecom, a druga ploča ukrašena je motivom rozete. Jedan je sanduk uokviren trakom s cik-cak linijama. Istočna i zapadna strana jednoga sanduka ukrašene su trakom s voluticama, a na zapadnoj strani je ukras s motivom mača sa štitom dok je na istočnoj strani ispod spomenute trake uklesana i trakica u vidu užeta. Na sjevernoj strani ovoga stećka nalazi se predstava kola sa 6 ženskih figura. Jedan sanduk ukrašen je motivom mača sa štitom, te križem i rozeticom, a uokviren tordiranom trakom. Na sljemenjaku s postoljem (dimenzija $187 \times 88 \times 105 \mathrm{~cm}$ ) sa sjeverne strane nalazi se predstava sa 6 figura koje se drže za ruke, na istočnoj strani nalaze se dvije figure, dok se na zapadnoj strani nalazi stilizirani ljiljan. Jedan sanduk ukrašen je motivom životinje a vrlo vjerojatno i čovjeka s kopljem (ukrasi su teško vidljivi). Također, na jednom sanduku od ukrasa nalazimo tordiranu traku, a na drugom sanduku motiv kamenice okružene tordiranom trakicom. Stećci su orijentirani u smjeru z-i.

U Međugorju nalazimo dva osamljena stećka na dva različita lokaliteta. Naime, na brdu Crnica, a na lokalitetu "Stanjevac", nalazi se osamljeni stećak u obliku sanduka, dimenzija 175 x 109 x $65 \mathrm{~cm}$, ukrašen motivima križa i kamenice. Ovaj stećak spominju M. Vego i R. Jolić koji navodi kako je posljednjih godina stećak bio otuđen ali je vraćen na njegovo prvobitno mjesto, dok je M. Sivrić na ovom lokalitetu evidentirao 2 stećka. ${ }^{89}$ Drugi lokalitet u Međugorju spominje

87 Kako je spomenuto, ovaj lokalitet prema podatcima iz katastra nosi ime "Glavica" i pripada ovom naselju. http://www.katastar.ba/geoportal/preglednik/ (22. 3. 2018.).

88 Arheološki leksikon Bosne i Hercegovine, sv. III., str. 294.

89 M. Vego, Historija Brotnja od najstarijih vremena do 1878. godine, str. 153; R. Jolić, Župa Međugorje, str. 50; Marijan Sivrić, Međugorje i Bijakovići u Brotnju, Mjesna zajednica Međugorje, Međugorje, 1979., str. 30. Priču o otu- 
R. Jolić, a riječ je o osamljenom stećku na putu prema groblju "Junčuša"..${ }^{90} \mathrm{Na}$ lokalitetu smo evidentirali sanduk vrlo malih dimenzija na koji je kasnije postavljen kamen s natpisom "Biskup Smoljan i njegov dom 1622-1700".

U selu Paoča stećke nalazimo na pet lokaliteta. Valja odmah napomenuti da u ovome selu Bešlagić ne navodi nijednu nekropolu, dok Vego piše kako u seoskome groblju u Paoči ima samo jedan stećak s natpisom, a Arheološki leksikon Bosne i Hercegovine navodi lokalitete "Krešića groblje" i "Paoča". ${ }^{91} \mathrm{U}$ novije vrijeme taj je popis dopunjen s dva lokaliteta od kojih je s jednim od njih javnost upoznao I. Dugandžić, a s drugim R. Jolić. ${ }^{22}$ Uvidom na terenu evidentirani su srednjovjekovni nadgrobni spomenici na sva četiri lokaliteta, a osim njih evidentirali smo još jedan lokalitet koji do sada nije nigdje bio spomenut.

Lokalitet poznat iz dosadašnje literature je rimokatoličko groblje "Oborine", na kojemu je evidentiran osamljeni stećak u obliku ploče, orijentiran u smjeru z-i, ukrašen "viticom"93 a na njemu je uklesan natpis: "†A se piše ot'cu (ocu) Mil'nu (Milanu) sin' (Radič)". ${ }^{4} \mathrm{Na}$ lokalitetu smo utvrdili kako je riječ o sanduku (dimenzija 223 x 128 x $47 \mathrm{~cm}$ ) čija je gornja ploha ukrašena vinovom lozicom s trolistovima. Stećak je postavljen u smjeru z-i.

đivanju ovoga stećka ispričao nam je također i mještanin Dragan Kozina (6. 4. 2016.). Valja napomenuti da M. Vego i M. Sivrić u Međugorju navode još neke lokalitete sa stećcima kojih danas više nema. Te podatke u novije vrijeme provjeravao je i R. Jolić, koji navodi kako je ranije postojala nekropola kod stare crkve sv. Jakova, ali danas na području Bijakovića nema nijednoga stećka. Usp. R. Jolić, Župa Međugorje, str. 49-50.

90 R. Jolıć, Župa Međugorje, str. 50. Stećak se nalazi na zemljišnoj čestici s nazivom "Zidina". http://www.katastar.ba/geoportal/preglednik/ (22. 3. 2018.).

91 M. VEgo, Historija Brotnja od najstarijih vremena do 1878. godine, str. 156; Arheološki leksikon Bosne i Hercegovine, sv. III., str. 301, 304.

92 I. Dugandžıć, "Nekropole stećaka u župi Gradnići", str. 233; R. Jolić, Župa Brotnjo - Gradnići, str. 42-44.

93 M. Vego, Historija Brotnja od najstarijih vremena do 1878. godine, str. 139; Arheološki leksikon Bosne i Hercegovine, sv. III., str. 304; I. DugAndžIć, "Nekropole stećaka u župi Gradnići", str. 233; R. Jolić, Župa Brotnjo - Gradnići, str. 43-44.

94 Navedeno prema: M. Vego, Historija Brotnja od najstarijih vremena do 1878. godine, str. 139. O natpisu vidi također: M. ŚImIć, "Jezik natpisa na stećcima u Brotnju", str. 64; M. ŠImIć, Jezik srednjovjekovnih kamenih natpisa iz Hercegovine, str. 94-95; R. Jolıć, Župa Krista Kralja u Čitluku, str. 55. Zanimljivo je spomenuti da se u 108 natpisa na stećcima (od oko njih 300 koje je objavio M. Vego) 


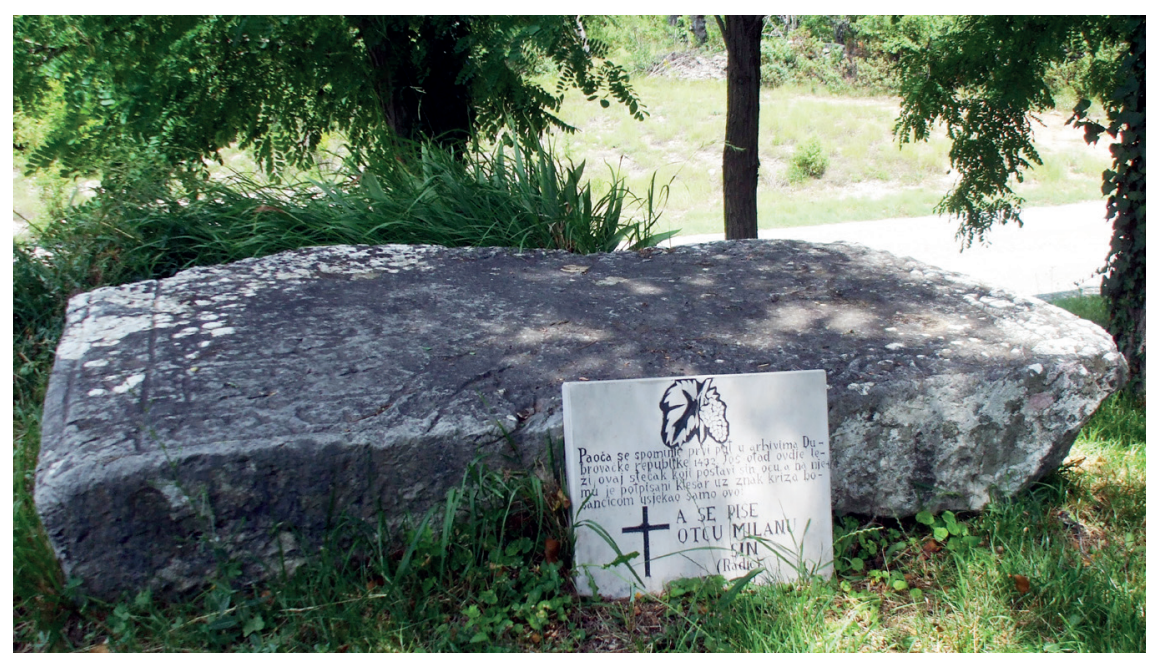

Stećak na groblju "Oborine" u Paoči (foto: D. Korać)

Drugi lokalitet nosi naziv "Krešića groblje", ${ }^{95}$ a to je ujedno i najveća nekropola u Paoči. Naime, u Arheološkom leksikonu Bosne i Hercegovine stoji da na ovome lokalitetu postoji nekropola s oko 20 stećaka koji su raspoređeni u dvije skupine i orijentirani z-i, a od ukrasa navodi se rozeta. ${ }^{96} \mathrm{U}$ novije vrijeme na ovoj je nekropoli Dugandžić evidentirao 17 stećaka, a taj broj potvrđuje i R. Jolić. Dok Dugandžić navodi kako su tri stećka ukrašena bordurom, rozetom i "nepo-

nalazi znak križa, i to uglavnom na početku natpisa. Također, Vego navodi da na 167 nekropola u Hercegovini (od 284 istražene) postoji simbol križa. Valja spomenuti da se na ovom kao i na drugim natpisima radi o simboličkoj invokaciji križa što je povezano sa suvremenim ćiriličnim poveljama. Više o tome, te o zastupljenosti i značenju simbola križa na stećcima vidi u: MARKo Vego, "Patarenstvo u Hercegovini u svjetlu arheoloških spomenika", u: Glasnik Zemaljskog muzeja u Sarajevu, n. s., arh., sv. XVIII., Sarajevo, 1963., str. 200-206; D. LovRENOvić, "Epitafi - 'knjige života"', str. 204; D. Lovrenović, Stećci. Bosansko i humsko mramorje srednjeg vijeka, str. 112-113; MiLko BRKović, Srednjovjekovna Bosna i Hum: identitet i kontinuitet, Crkva na kamenu, Mostar, 2010., str. 283; Milko BRKović, "Diplomatičko-povijesna pozadina sadržaja Kočerinske ploče", u: Grgo Mikulić (ur.), Zbornik: Viganj i njegovo doba, GRAL - Odbor za obilježavanje 600. obljetnice, Široki Brijeg - Kočerin, 2004., str. 65-67.

95 Nekropola se nalazi na zemljišnim česticama s nazivima "Kvečića groblje" (sic!) i "Ćorića ulica". Usp. http://www.katastar.ba/geoportal/preglednik/ (22. 3. 2018.).

96 Arheološki leksikon Bosne i Hercegovine, sv. III., str. 301. 
znatim ukrasom", Jolić piše kako su neki stećci ukrašeni rozetama, na gornjoj plohi jedne ploče vidi se polumjesec, a na plohi jednoga stećka u obliku ploče vide se utori sa strana za koje pretpostavlja da je klesar počeo raditi borduru ili čak štit $s$ mačem. ${ }^{97}$ Obilaskom lokaliteta mještani su nam potvrdili kako je jedan broj stećaka iz vinograda pomaknut na obližnju livadu. Budući da je jedan broj stećaka zarastao, nemoguće je odrediti konačan broj. Prema tome, sa sigurnošću možemo kazati da se na nekropoli nalazi oko 16 stećaka od čega 5 ploča, 7 sanduka, 1 stećak amorfnog oblika, a do 3 stećka nismo mogli pristupiti. Od ukrasa pojavljuju se motivi rozete, mladoga mjeseca i bordure. Stećci su postavljeni u smjeru z-i, osim tri stećka koji se nalaze u položaju s-j. Ukrašena su samo tri stećka. Na jednome stećku u obliku ploče nalazimo motiv mladoga mjeseca i rozete. Također, motiv rozete nalazimo i na jednome sanduku dok je na drugome sanduku gornja ploha uokvirena.

U blizini navedenoga lokaliteta je vrelo "Palačak" na kojemu se nalazi korito isklesano od jednoga velikog stećka. ${ }^{98}$

U novije vrijeme podatke o još jednom lokalitetu donio je, kako je spomenuto, R. Jolić, koji je zabilježio dva stećka ("Ćorića stećci" kako ih navodi) u obliku ploče. Prema njegovu navodu gornja ploha jedne ploče ukrašena je cik-cak bordurom, a na jednom kraju stećka nalazi se rozeta pa Jolić pretpostavlja da se i na drugome kraju stećka nalazi isti ukras koji je danas teško vidljiv. ${ }^{99} \mathrm{Mi}$ smo ovaj lokalitet imenovali "Podvornica", ${ }^{100}$ kako glasi ime zemljišne čestice na kojoj se nalaze ovi stećci. Zbog nepristupačnosti lokaliteta nismo bili u mogućnosti detaljnije pogledati ove stećke (1 sanduk i jedna ploča). Smjer njihova pružanja je nejednak.

Posljednji lokalitet u Paoči, koji do sada nije bio nigdje evidentiran nazvali smo "Dodigovac", također prema njegovu nazivu u kata-

97 I. DugAndžić, "Nekropole stećaka u župi Gradnići", str. 233; R. Jolić, Župa Brotnjo - Gradnići, str. 42-43.

98 Ovaj stećak prvi spominje I. Dugandžić. O tome: I. Dugandžıć, "Nekropole stećaka u župi Gradnići", str. 233. R. Jolić pretpostavlja da je ovo bio najveći i najljepši stećak na "Krešića groblju" odakle je premješten na ovo mjesto. $\mathrm{O}$ tome više u: R. Jolić, Župa Brotnjo - Gradnići, str. 43.

99 R. Jolić, Župa Brotnjo - Gradnići, str. 44-45.

100 http://www.katastar.ba/geoportal/preglednik/ (27. 3. 2018.). 
stru. ${ }^{101}$ Ovdje se nalaze 3 jednostavno obrađena stećka koji su utonuli u zemlju, bez ukrasa. Postavljeni su u smjeru z-i.

U selu Služanj nalazimo četiri lokaliteta sa stećcima. Prvi lokalitet nosi ime "Grmak", gdje Bešlagić navodi 8 dobro obrađenih stećaka bez ukrasa, orijentiranih u smjeru z-i, a iste podatke nalazimo i u Arheološkome leksikonu Bosne i Hercegovine. S druge strane, Jolić je na ovom lokalitetu zabilježio 7 stećaka (3 sanduka i 4 ploče). ${ }^{102}$ Pregledom lokaliteta utvrđeno je kako se na nekropoli nalazi 7 stećaka, i to 5 sanduka, jedna ploča a jedan stećak zarastao je u raslinje i djelomično je oštećen. Spomenici su orijentirani u smjeru z-i i nemaju ukrasa.

O drugom lokalitetu s imenom "Orlac"103 do sada su pisali Š. Bešlagić, M. Vego, N. Miletić (Arheološki leksikon Bosne i Hercegovine) i R. Jolić. Dok Bešlagić navodi skupinu od 50 stećaka, Vego i Jolić spominju broj od 45 stećaka a isti broj nalazi se i u Arheološkome leksikonu Bosne i Hercegovine. Prema Bešlagiću obrada spomenika je slaba, više stećaka je utonulo u zemlju, postavljeni su u smjeru z-i, a dva su stećka ukrašena motivom križa s kamenicom i dvostrukoga križa. ${ }^{104}$ Nekropola je u vrlo lošem stanju, a evidentirali smo 48 stećaka. Ukrašena su samo dva stećka, i to jedan sanduk s motivom križa i kamenice, a drugi sanduk ukrašen je motivom dvostrukoga križa. Više je stećaka oštećeno, utonulo u zemlju i zaraslo raslinjem pa smo zbog stanja na nekropoli mogli evidentirati samo 7 sanduka, 3 ploče te 8 amorfnih, dok su tri stećka ugrađena u ogradu vrta. Spomenici su orijentirani u smjeru z-i.

101 http://www.katastar.ba/geoportal/preglednik/ (27. 3. 2018.).

102 Usp. Š. BeŠLagić, Stećci. Kataloško-topografski pregled, str. 316; Arheološki leksikon Bosne i Hercegovine, sv. III., str. 298; R. JolIĆ, Župa Krista Kralja u Čitluku, str. 65-66. Ovaj lokalitet pod nazivom "Grmci" nalazimo u Bešlagića i u Arheološkome leksikonu Bosne i Hercegovine, a pod nazivom "Grmak" kod Jolića. Vrijedi spomenuti da se u katastru nalaze zemljišne čestice s oba ova naziva, a nalaze se u neposrednoj blizini. Usp. http://www.katastar.ba/geoportal/preglednik/ (27. 3. 2018.).

103 Mještani ovaj lokalitet zovu "Orlac", a zemljišna čestica na kojoj se nalaze stećci u katastru zove se "Stećni" (sic!). http://www.katastar.ba/geoportal/ preglednik/ (27. 3. 2018.).

104 Š. BeŠLAGić, Stećci. Kataloško-topografski pregled, str. 316; M. VEGo, Historija Brotnja od najstarijih vremena do 1878. godine, str. 156; Arheološki leksikon Bosne i Hercegovine, sv. III., str. 304; R. Jolić, Župa Krista Kralja u Čitluku, str. 64-65. 
Treći lokalitet vodimo pod nazivom "Sančevina" kako glasi ime ovoga lokaliteta u katastru, a radi se o stećcima u aktivnom rimokatoličkom groblju. ${ }^{105}$ Nedaleko od ovoga groblja nalazi se još jedan lokalitet pa su neki autori ova dva lokaliteta navodili zajedno, ${ }^{106}$ dok su ih neki navodili posebno, i to pod nazivima "Sančevine" i "Stećci (Kekinovac)". ${ }^{107}$ Bešlagić je na ova dva lokaliteta zabilježio 12 stećaka (11 sanduka i 1 sljemenjak), orijentiranih u smjeru z-i, dobro očuvani i obrađeni, od kojih je ukrašeno 5 sanduka i 1 sljemenjak (ukrasi su: bordura i friz od povijene lozice s trolistovima, arkade, štit $s$ mačem i scena lova na jelena). ${ }^{108}$ Vego u samom groblju navodi 9 stećaka od

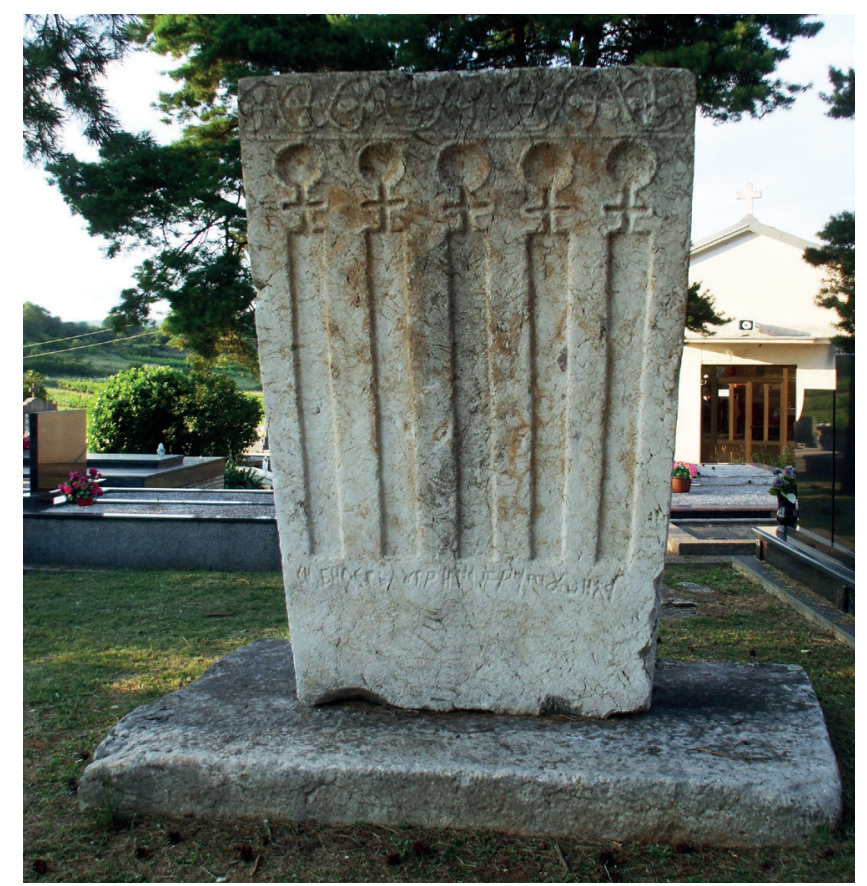

Stećak s natpisom Ugrina Vratušića na groblju "Sančevina" u Služnju (foto: D. Korać)

105 http://www.katastar.ba/geoportal/preglednik/ (27. 3. 2018.).

106 Š. BEŠLAGIĆ, Stećci. Kataloško-topografski pregled, str. 316; M. VEGo, Historija Brotnja od najstarijih vremena do 1878. godine, str. 156. Zbog vrlo male udaljenosti ovih lokaliteta može se pretpostaviti da je u srednjem vijeku to bila jedna nekropola.

107 Arheološki leksikon Bosne i Hercegovine, sv. III., str. 305-306; R. Jolić, Župa Krista Kralja u Čitluku, str. 66-67.

108 Š. BeŠLAGIĆ, Stećci. Kataloško-topografski pregled, str. 316. 
kojih ističe jednu ploču koja je na gornjoj plohi ukrašena trolistovima. ${ }^{109} \mathrm{~N}$. Miletić je u katoličkom groblju zabilježila 6 stećaka u obliku ploča, sanduka i visokoga sanduka, orijentiranih u smjeru z-i, a od ukrasa navodi viticu, arkade i štit s mačem. ${ }^{110}$ Jolić ovdje bilježi 6 stećaka (1 visoki sanduk s postoljem, 2 sanduka, jedna ploča i dvije amorfne ploče bez ukrasa), donoseći vrlo detaljne opise svakoga od njih. ${ }^{111} \mathrm{Na}$ lokalitetu smo evidentirali 7 stećaka (1 visoki sanduk s postoljem, 2 sanduka, jedna ploča i 3 stećka utonula u zemlju). Orijentirani su u smjeru z-i osim dva stećka koji su postavljeni u smjeru j-s. Tri stećka su ukrašena. Naime, gornja ploha jednoga sanduka ukrašena je štitom i mačem, a jedna ploča ukrašena je vinovom lozicom s trolistovima. Svakako je najbogatije ukrašen visoki sanduk s postoljem, čija se ljepota zaista pokazala u punom sjaju nakon što je 2013. godine na Jolićevu inicijativu ovaj stećak postavljen u prvobitni položaj. Najveće otkriće bio je natpis Ugrina Vratušića ("Ovo [je] bilig Ugrina Vratušića") koji donosi Radoslav Dodig, te detaljno opisuje ovaj nadgrobni spomenik, izražavajući žaljenje što navedene godine nije provedeno arheološko istraživanje nego je ploča "nivelirana i učvršćena betonskom smjesom". ${ }^{112}$ Ovaj stećak ukrašen je visokim arkadama s potkovičastim lukovima, i to na sjevernoj i južnoj strani po pet, a na istočnoj i zapadnoj po dvije, dok se na vrhu nalazi "reljefni friz od crte u obliku užeta i spiralnih vitica loze s trolistom". ${ }^{113}$

Nedaleko od ovoga groblja, kako je spomenuto, nalazi se lokalitet s nazivom "Stećci (Kekinovac)". ${ }^{114}$ Vego je pišući o stećcima "izvan groblja" od "nekoliko stećaka", kako navodi, posebno upozorio na jedan od njih (sljemenjak s odvojenim kamenim postoljem) ističući na njemu ukras "6 plastičnih likova mačeva - arkadica" od kojih se na jednoj od njih nalazi osmokraka zvijezda, što je po njegovu mišljenju

109 M. Vego, Historija Brotnja od najstarijih vremena do 1878. godine, str. 156.

110 Arheološki leksikon Bosne i Hercegovine, sv. III., str. 305.

111 R. Jolić, Župa Krista Kralja u Čitluku, str. 66-67.

112 O tome više u: Robert Jolić, "Uređivanje stećaka na Služnju", u: Naša ognjišta, 7-8, Tomislavgrad, 2013., str. 18; https://arheohercegovina.com/2013/07/23/ bilig-u-sluznju/, Radoslav Dodig, Bilig u Služnju (2. 4. 2018.).

113 https://arheohercegovina.com/2013/07/23/bilig-u-sluznju/, RADOsLAV DoDIG, Bilig u Služnju (2. 4. 2018.).

114 Lokalitet je pod ovim nazivom evidentirala N. Miletić, a potom i R. Jolić. Smatramo da je ovaj naziv najtočniji jer se u katastru zemljišne parcele na kojima se nalaze ovi stećci zovu "Kekinovac" i "Steći" (sic!). Usp. http://www. katastar.ba/geoportal/preglednik/ (2. 4. 2018.). 
jedinstven primjer u Hercegovini i vjerojatno ukazuje na heraldičko značenje ove predstave. ${ }^{115} \mathrm{~N}$. Miletić je na ovom lokalitetu zapisala 4 stećka u obliku ploče, sanduka, visokog sanduka i sljemenjaka, a od ukrasa navodi: borduru, rozetu, friz lukova, štit s mačem i arkade. ${ }^{116}$ Iste podatke donosi i Jolić a detaljnije opisuje tri stećka. ${ }^{117}$ Provjerom lokaliteta evidentirali smo 5 stećaka (1 sanduk, 1 sanduk na postolju, 1 sljemenjak na postolju i dvije ploče) orijentiranih u smjeru z-i. Ukrašena su dva sanduka i jedan sljemenjak. Naime, sanduk na postolju ukrašen je s pet visokih arkada na sjevernoj i južnoj strani, a iznad arkada nalazi se motiv vinove lozice koja okružuje stećak. Jedan je sanduk okružen vinovom lozicom na gornjoj plohi, gdje se nalazi i mač sa štitom, a na sjevernoj strani nalazi se prikaz lova (muška figura s kopljem na konju u lovu na dvije veće životinje). Sljemenjak na postolju ukrašen je na sljedeći način: tordirana traka ukrašava dio krova i zabata, ispod nje nalazi se traka s lukovima i trokutovima koja okružuje gornji dio strana sljemenjaka. $\mathrm{Na}$ južnoj strani nalazi se šest arkada s potkovičastim lukovima i rozetica koja povezuje prve dvije arkade, a motiv šest arkada pojavljuje se i na sjevernoj strani sljemenjaka, ali bez rozetice.

U selu Tepčići lokalitet sa stećcima, u literaturi poznat kao "Crkvina", nalazi se pokraj rimokatoličkoga groblja. Podatke o ovoj nekropoli nalazimo u Š. Bešlagića, M. Vege i u Arheološkome leksikonu Bosne i Hercegovine. Bešlagić navodi da se na ovome lokalitetu nalazi nekropola s 39 stećaka (27 sanduka, 10 ploča i 2 sljemenjaka), orijentiranih u smjeru z-i, te da su samo dva stećka ukrašena (tordirana vrpca i križ). Isti broj srednjovjekovnih spomenika na ovome lokalitetu naveden je i u Arheološkome leksikonu Bosne i Hercegovine, dok Vego za ovaj lokalitet navodi broj od 36 stećaka "raznih oblika i veličina", a od ukrasa spominje samo križ na jednome stećku. ${ }^{118}$ Provjerom lokaliteta utvrđeno je kako se na ovoj nekropoli nalazi 37 stećaka od čega 3 ploče, 11 sanduka, 2 sljemenjaka, 18 amorfnih stećaka i 3 stećka utonula u zemlju. Prema kazivanju mještana jedan je stećak otuđen u zadnje vrijeme. Ukrašena su četiri stećka. Naime, na jed-

115 M. Vego, Historija Brotnja od najstarijih vremena do 1878. godine, str. 156.

116 Arheološki leksikon Bosne i Hercegovine, sv. III., str. 306.

117 R. Jolić, Župa Krista Kralja u Čitluku, str. 67.

118 Š. BeŠLagić, Stećci. Kataloško-topografski pregled, str. 317; Arheološki leksikon Bosne i Hercegovine, sv. III., str. 292; M. VEgo, Historija Brotnja od najstarijih vremena do 1878. godine, str. 157. 
nome sanduku nalazimo motiv kamenice. Jedan je sanduk ukrašen motivom rozete, a na druga dva sanduka je uz motiv rozete moguć i motiv tau križa (?). Postoji mogućnost da se ovaj motiv nalazi i na još dva stećka (odnosno jednoj ploči i jednome sanduku). Inače, stećci su postavljeni u smjeru z-i, osim dva stećka koji se nalaze u smjeru s-j.

U Tepčići Polju, na nekoliko zemljišnih čestica koje se nalaze u neposrednoj blizini, evidentirali smo 33 stećka. Naši se rezultati uvelike razlikuju od Bešlagićevih, a koje u Arheološkom leksikonu Bosne $i$ Hercegovine ponavlja i N. Miletić. Naime, kod njih se nalaze podatci o dva lokaliteta koji nisu jasno ubicirani. Uz prvi lokalitet Bešlagić navodi 50 stećaka koji su raspoređeni u tri skupine, a prema njegovu navodu 20 ih je u obliku ploče, 30 u obliku sanduka, većina je utonula u zemlju a ima i amorfnih. Nadalje, navodi kako su 4 stećka ukrašena (jedna ploča i 3 sanduka), a njihovi motivi su: rozeta, arkade, stilizirani križ, polumjesec, bordura od cik-cak linija i predstava konja s jahačem. Sam Bešlagić na kraju pak navodi kako podatci nisu sasvim sigurni. ${ }^{119} \mathrm{Na}$ drugom lokalitetu bilježi 13 stećaka (1 ploča i 12 sanduka), od kojih su ukrašeni samo ploča i visoki sanduk, a od ukrasa se navode: bordura, stilizirani križ, arkade te konjanik. ${ }^{120} \mathrm{~S}$ druge strane M. Vego donosi drugačije podatke s preciznijim opisom lokaliteta. ${ }^{121}$ Uvidom na lokalitetu potvrđeno je da se svi ovi srednjovjekovni spomenici nalaze u neposrednoj blizini. Naime, na zemljišnim česticama "Bašča" i "Velika njiva"122 koje se nalaze jedna uz drugu nalazi se više stećaka. Na zemljišnoj čestici koja se nalazi u posjedu obitelji Jerkić nalazi se 5 stećaka (od kojih jedan u njihovu dvorištu), a na čestici koja pripada obitelji Miloš nalazi se 17 stećaka. Što se tiče oblika navedenih stećaka, evidentirali smo dvije ploče, 4 sanduka, 10 ih je utonulo u zemlju, 3 amorfna, 2 su bila nepristupačna, a 1 stećak je ugrađen u obližnji zid. Dva su stećka ukrašena motivima polumjeseca i kamenice. Stećci su orijentirani u smjeru z-i.

119 Š. BEŠLAGIĆ, Stećci. Kataloško-topografski pregled, str. 341. Isti broj stećaka na ovoj nekropoli, ali s puno sažetijim podatcima, donosi i N. Miletić. Usp. Arheološki leksikon Bosne i Hercegovine, sv. III., str. 309.

120 Š. BEŠLAGIĆ, Stećci. Kataloško-topografski pregled, str. 340-341. Sažetije podatke donosi N. Miletić. Usp. Arheološki leksikon Bosne i Hercegovine, sv. III., str. 309.

121 O tome vidi u: M. Vego, Historija Brotnja od najstarijih vremena do 1878. godine, str. 159-160.

122 http://www.katastar.ba/geoportal/preglednik/ (23. 3. 2018.). 
U susjednom dvorištu (na zemljišnoj čestici istoga imena) nalazi se 9 stećaka utonulih u zemlju. Na susjednoj zemljišnoj čestici s nazivom "Stećak"123 nalaze se 2 stećka (visoki sanduk s postoljem i ploča). ${ }^{124}$ Stećci su obrasli gustim raslinjem, pa je pristup ovim nadgrobnim spomenicima vrlo težak. Visoki sanduk s postoljem (dimenzija $206 \mathrm{x}$ 132 x $55 \mathrm{~cm}$ ) plijeni pažnju, a svojim izgledom podsjeća na stećke u Služnju. Sjeverna i južna strana ovoga stećka ukrašene su arkadama s potkovičastim lukovima, iznad arkada nalazi se friz s tordiranom debljom trakom, a sa sjeverne strane ispod arkada moguć je prikaz lovca s povijenom rukom i kopljem.

Prvi i zasigurno najpoznatiji lokalitet u Velikom Ograđeniku je "Visočica". ${ }^{25}$ Valja odmah napomenuti kako se na ovoj nekropoli nalaze čak 4 natpisa obitelji Komlinovića i jedinstveni primjer natpisa na postolju, ali se, na žalost, o ovoj vrijednoj nekropoli ne vodi dovoljna briga. Na ovome lokalitetu Bešlagić navodi 37 stećaka (28 sanduka i 9 sljemenjaka), koji su raspoređeni u dvije skupine, te da su neki stećci utonuli u zemlju, a kao "jedinstvenu pojavu" navodi dva sljemenjaka na jednom postolju. Prema njegovim navodima ukrašeno je 11 stećaka (5 sanduka i 6 sljemenjaka), a ukrasni motivi su obična i tordirana traka, obična pravokutna bordura i bordura od povijene lozice s trolistovima, mladi mjesec, rozeta i križ dok su na tri sljemenjaka uklesana 4 natpisa. ${ }^{126} \mathrm{~S}$ druge strane, $\mathrm{M}$. Vego navodi kako se na ovome lokalitetu (navodi ga pod imenom "Pavluša") nalaze 33 stećka u obliku ploče, sanduka i sljemenjaka, a od ukrasa spominje križ, rozete i polumjesec. ${ }^{127}$ Broj od 39 stećaka na ovoj nekropoli nalazi se u Arheološkome leksikonu Bosne i Hercegovine, gdje je ovaj lokalitet naveden

123 http://www.katastar.ba/geoportal/preglednik/ (23. 3. 2018.).

$124 \mathrm{U}$ dosadašnjoj literaturi najviše pažnje ovome sanduku posvetio je M. Vego. O tome vidi u: M. Vego, Historija Brotnja od najstarijih vremena do 1878. godine, str. 159-160. Podatke o ovim stećcima Š. Bešlagić kao i N. Miletić donose u opisu nekropole koja prema njihovu navodu broji 13 stećaka, što smo već ranije spomenuli. Usp. Š. BEŠLAGić, Stećci. Kataloško-topografski pregled, str. 340-341; Arheološki leksikon Bosne i Hercegovine, sv. III., str. 309.

125 Područje na kojemu se nalazi ova nekropola zove se "Visočica", a zemljišna parcela na kojoj se nalazi većina ovih spomenika u katastru nosi naziv "Visočica - Stečak". http://www.katastar.ba/geoportal/preglednik/ (23. 3. 2018.).

126 Š. BEŠLAGIĆ, Stećci. Kataloško-topografski pregled, str. 315-316; Š. BEŠLAGIĆ, Leksikon stećaka, str. 66.

127 M. Vego, Historija Brotnja od najstarijih vremena do 1878. godine, str. 155. 


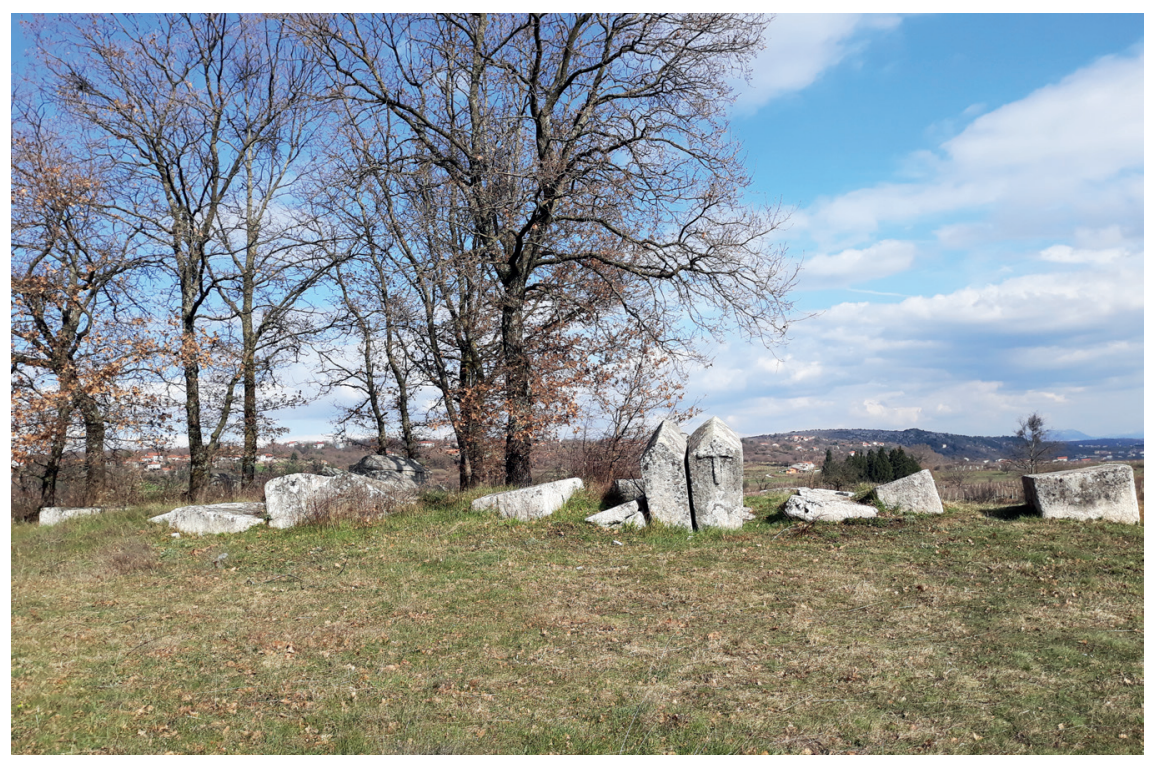

Nekropola "Visočica" - Veliki Ograđenik (foto: D. Korać)

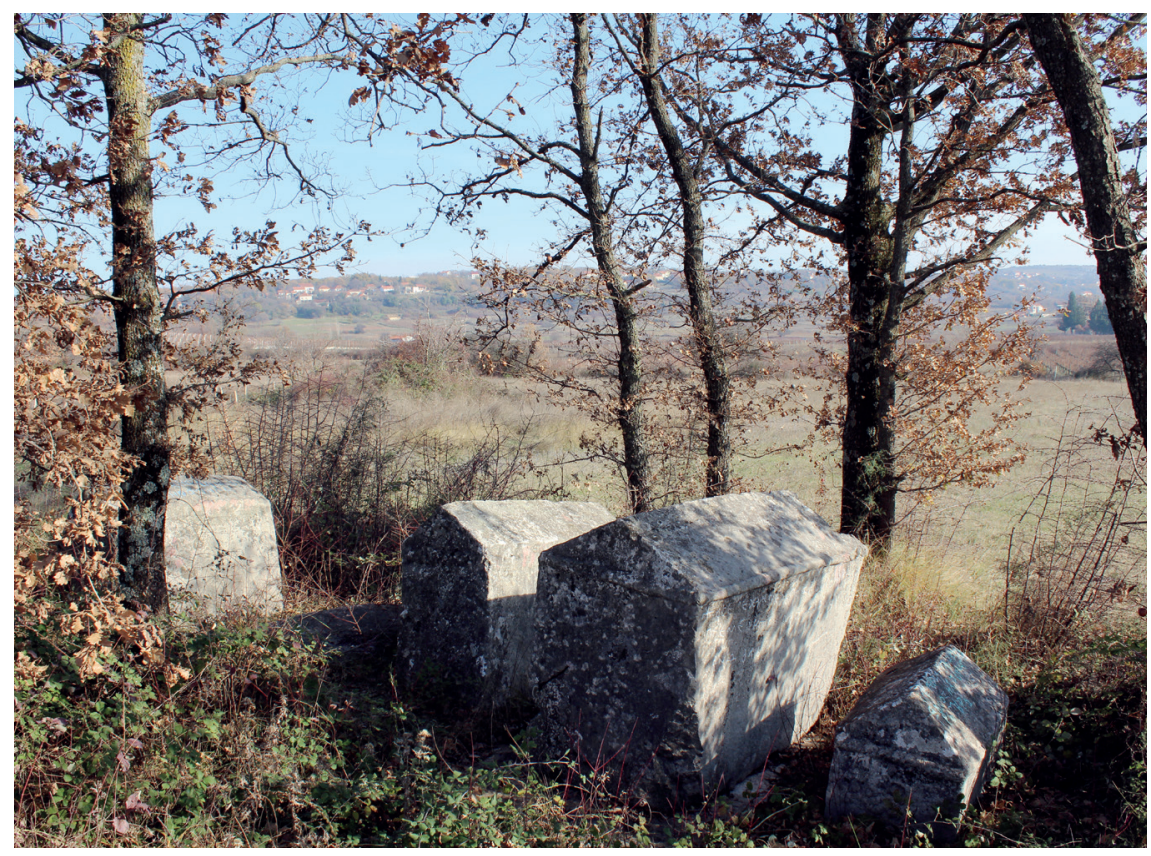

Sljemenjaci na nekropoli "Visočica" (foto: R. Mirković) 
uz naselje Donja Blatnica, što je pogrješno. ${ }^{128}$ Obilaskom lokaliteta zabilježili smo 40 stećaka od čega 8 ploča, 13 sanduka, 1 sanduk s postoljem, 4 sljemenjaka, 3 sljemenjaka s postoljem, 1 primjerak gdje su dva sljemenjaka postavljena na isto postolje te 10 stećaka utonulih u zemlju. Ukrašeno je 13 stećaka, a na 3 stećka uklesana su 4 natpisa plemićke obitelji Komlinović. Motivi su bordura, tordirana traka, tordirana traka s vinovom lozicom i trolistovima, križ, rozeta i mladi mjesec. Stećci su postavljeni u smjeru z-i i podijeljeni su u dvije skupine. Prvu skupinu čini 35 stećaka (8 ploča, 10 sanduka, 1 sanduk s postoljem, 4 sljemenjaka, 3 sljemenjaka s postoljem, 1 primjerak gdje su 2 sljemenjaka postavljena na isto postolje te 8 stećaka utonulih u zemlju). Jedan je sanduk ukrašen bordurom. Na jednome oštećenom stećku u obliku ploče ucrtan je motiv križa u kružnici, najvjerojatnije novijega datuma. Gornja ploha jednoga sanduka okružena je ukrasom vinove lozice s trolistom. Dva sljemenjaka na zajedničkom postolju ukrašena su motivom mladoga mjeseca s južne strane, sa zapadne strane motivom križa. Na jednome je sanduku gornja ploha ukrašena i podijeljena križem na 4 plohe od koje su dvije ukrašene mladim mjesecom i rozetom. Jedan stećak u obliku ploče ukrašen je motivom mladoga mjeseca. Gornja ploha jednoga sanduka s postoljem podijeljena je trakom. Također, gornja ploha jednoga stećka u obliku ploče podijeljena je trakom. Jedan sljemenjak na postolju, koji je utonuo u zemlju, okružen je tordiranom trakom. Nadalje, ukrašen je još jedan sljemenjak, i to $s$ uže strane tordiranom trakom a u zabatu se nalazi mladi mjesec. Na kraju donosimo opise stećaka s natpisima. Na sljemenjaku $(177$ x 58 x $134 \mathrm{~cm})$ koji je ukrašen tordiranom trakom, nalazi se natpis Ivaniša Komlinovića: "† A se leži Ivaniš' Komlinović"'. ${ }^{129}$ Jedan sljemenjak s postoljem, dimenzija 100 x 53 x 24 $\mathrm{cm}$, ukrašen je motivom rozete na užoj strani i okružen tordiranom trakom, a na njemu se nalazi natpis dječaka Grgura, sina Vukca Vukovića, iz plemena Komlinović koji glasi: "A se leži sin' Vukca Vuko-

128 Arheološki leksikon Bosne i Hercegovine, sv. III., str. 308.

129 Navedeno prema: M. Vego, Historija Broćna od najstarijih vremena do turske okupacije, str. 86. O natpisu vidi također: M. Vego, "Novi i revidirani ćirilski natpisi iz župe Broćno u Hercegovini", str. 226-227; M. VEGO, Zbornik srednjovjekovnih natpisa Bosne i Hercegovine, sv. I., str. 22-23; M. VEGo, Iz istorije srednjovjekovne Bosne i Hercegovine, str. 148-149; M. ŠImIć, "Jezik natpisa na stećcima u Brotnju", str. 61; M. Šımı́, Jezik srednjovjekovnih kamenih natpisa iz Hercegovine, str. 89. 
vića, a na ime Gr'gur'". ${ }^{130}$ Drugi sljemenjak na postolju, dimenzija 182 x 92 x $139 \mathrm{~cm}$, ukrašen je tordiranom trakom, a na njemu se nalazi natpis kneza Pavla Komlinovića: "† A se leži knez' Pavao Komlinović' na svoi plemenitoi na Prozračcu u dni voevode Sandala". ${ }^{131}$ Na postolju istoga sljemenjaka nalazi se duži natpis koji glasi: " $\dagger$ A se leži knez' Pavao Komlinović' na svoi plemenitoi na Prozračcu u dni voevode Sandala koi ga počteno i virno služaše. Učr'to, uč'to na plemenitei". 132 $\mathrm{Na}$ drugoj skupini stećaka (3 sanduka i 2 stećka utonula u zemlju) nema ukrasnih motiva ni natpisa.

Sljedeći lokalitet u Velikom Ograđeniku (Donji) nosi ime "Krstine", ${ }^{133}$ gdje je Bešlagić evidentirao nekropolu s 9 stećaka (4 ploče, 4 sanduka

130 Navedeno prema: M. Vego, Historija Broćna od najstarijih vremena do turske okupacije, str. 88. O natpisu vidi također: M. VEGo, "Novi i revidirani ćirilski natpisi iz župe Broćno u Hercegovini", str. 227-228; M. VEGo, Zbornik srednjovjekovnih natpisa Bosne i Hercegovine, sv. I., str. 24-25; M. VEGO, Iz istorije srednjovjekovne Bosne i Hercegovine, str. 150-151; M. ŠImIĆ, "Jezik natpisa na stećcima u Brotnju", str. 61; M. Šımı́́, Jezik srednjovjekovnih kamenih natpisa iz Hercegovine, str. 89-90.

131 Navedeno prema: M. Vego, Historija Broćna od najstarijih vremena do turske okupacije, str. 90. O natpisu vidi također: M. VEGo, "Novi i revidirani ćirilski natpisi iz župe Broćno u Hercegovini", str. 228-232; M. VEGo, Zbornik srednjovjekovnih natpisa Bosne i Hercegovine, sv. I., str. 24-25; M. VEGO, Iz istorije srednjovjekovne Bosne i Hercegovine, str. 151-156; M. Šımıć, "Jezik natpisa na stećcima u Brotnju", str. 62; M. Šımı́́, Jezik srednjovjekovnih kamenih natpisa iz Hercegovine, str. 90. Valja spomenuti da je M. Vego iznio brojčane podatke za svaki stalež pokojnika na čijem se nadgrobnom spomeniku nalazi natpis (ukupno 195 natpisa u Hercegovini), iz čega je evidentno da je $1 / 3$ ovih natpisa vezana uz feudalnu klasu, gotovo $1 / 3$ odnosi se na slobodne ljude, a preostali dio "pripada anonimnim ili neutvrđenim imenima pokojnika". M. VEGo, "Patarenstvo u Hercegovini u svjetlu arheoloških spomenika", str. 203-204. O socijalnoj raspodjeli natpisa vidi i u: D. LovreNOvić, Stećci. Bosansko i humsko mramorje srednjeg vijeka, str. 116-118; D. Lovrenović, "Epitafi - 'knjige života"', str. 214-215.

132 Navedeno prema: M. VEgo, Historija Broćna od najstarijih vremena do turske okupacije, str. 90. O natpisu vidi također: M. VEGo, "Novi i revidirani ćirilski natpisi iz župe Broćno u Hercegovini", str. 232-234; M. VEGo, Zbornik srednjovjekovnih natpisa Bosne i Hercegovine, sv. I., str. 26-27; M. VEGO, Iz istorije srednjovjekovne Bosne i Hercegovine, str. 156-158; M. Šimić, "Jezik natpisa na stećcima u Brotnju", str. 62; M. Šı Ić, Jezik srednjovjekovnih kamenih natpisa iz Hercegovine, str. 90. Više o tome kao i o značenju ovakvih natpisa kao dokumenata koji govore o nasljednom pravu koje plemići imaju na zemlju na kojoj su sahranjeni vidi u: D. Lovrenović, Stećci. Bosansko i humsko mramorje srednjeg vijeka, str. 104-108.

133 http://www.katastar.ba/geoportal/preglednik/ (23. 3. 2018.). 
i 1 križ s pločom). Prema njegovu navodu, spomenici su orijentirani u smjeru z-i, ukrašeno je 5 stećaka (4 ploče i jedan križ), i to motivima bordure od povijene lozice s trolistovima, arkadama, štitom $s$ mačem, mladim mjesecom i rozetom. ${ }^{134} \mathrm{U}$ Arheološkome leksikonu Bosne i Hercegovine na ovome lokalitetu (evidentiran kao "Miličevića Krstine") navodi se broj od 10 stećaka. ${ }^{135} \mathrm{M}$. Vego na ovom lokalitetu bilježi 5 sanduka i dvije ploče, te donosi detaljni opis velikoga križa (po kojemu je ova nekropola i dobila ime). ${ }^{136} \mathrm{Na}$ lokalitetu smo evidentirali 7 stećaka od čega 4 sanduka, dvije ploče i 1 križ u kombinaciji sa sandukom. ${ }^{137}$ Ukrašena su 4 stećka, i to motivima bordure, tordiranom trakom, vinovom lozicom s trolistovima, rozetom, mladim mjesecom, arkadom i mačem sa štitom. Gornja ploha jednoga stećka u obliku ploče podijeljena je na dva dijela tankom bordurom i uokvirena tordiranom trakom $s$ vinovom lozicom s trolistovima, ukrašena motivom rozete i mača sa štitom s malom rozeticom. Jedan sanduk uokviren je plastično obrađenom tordiranom trakom s trolistovima i motivom mača sa štitom. Jedna ploča ukrašena je tordiranom trakom od vinove lozice s trolistom, rozetom i mladim mjesecom. Ukrase nalazimo na još jednom stećku (križ u kombinaciji sa sandukom) na kojemu je križ ukrašen arkadicama, i to s jedne strane osam, a s druge pet arkada.

U Velikom Ograđeniku u katoličkom groblju "Čmarevac" nalazi se veliki nadgrobni spomenik u obliku sanduka ${ }^{138}$ impozantnih dimenzija 262 x 230 x 67, orijentiran u smjeru z-i. Ovaj stećak plijeni pažnju

134 Š. BEŠLAGIĆ, Stećci. Kataloško-topografski pregled, str. 315.

135 Interesantno je da se autorica poziva na Bešlagićeve rezultate ali se broj evidentiranih stećaka razlikuje. Usp. Arheološki leksikon Bosne i Hercegovine, sv. III., str. 303.

136 M. Vego, Historija Brotnja od najstarijih vremena do 1878. godine, str. 155.

137 Dimenzije križa su 171 x 208 x 36 cm, a dimenzije sanduka 297 x 248 x 50 $\mathrm{cm}$. Zanimljivo je spomenuti da je, prema pričanju mještana, križ bio viši nego što smo evidentirali na lokalitetu. Naime, prije oko 50 godina mladići iz sela ovaj su križ vratili u prvobitni položaj (nakon što se bio nakrivio) te je tom prilikom u zemlju ukopan veći dio križa nego onaj koji se danas vidi iznad površine. Navedeno prema pričanju Vidaka Miličevića (Mave), Joze Miličevića i Blage Miličevića (15. 5. 2016.).

138 Arheološki leksikon Bosne i Hercegovine, sv. III., str. 296; R. Jolić, "Groblja u čerinskoj župi", str. 193. U navedenoj literaturi ovaj je stećak evidentiran kao ploča. Zemljišna čestica na kojoj se nalazi groblje u katastru zove se "Čmarevac". http://www.katastar.ba/geoportal/preglednik/ (24. 3. 2018.). 


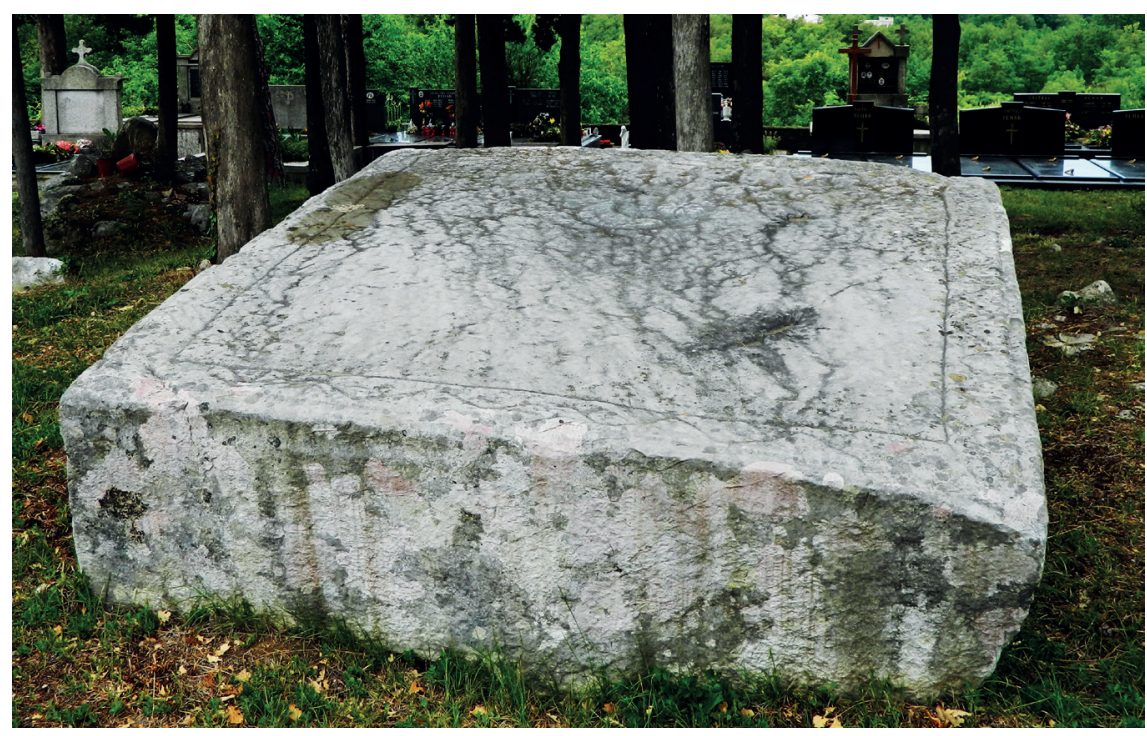

Stećak u groblju "Čmarevac" - Gornji Veliki Ograđenik (foto: D. Korać)

svojim ukrasima, čija ljepota do sada nije bila dovoljno prepoznata. Naime, stećak je ukrašen sa svih strana, a od ukrasa nalazimo borduru, polumjesec, rozetu, čekić?, kolo s osam plesača od kojih je jedan muškarac, te figuralne scene lova. Gornja ploha sanduka uokvirena je bordurom od cik-cak linija, a na njoj se nalaze i motivi: rozeta, polumjesec, čekić?, te kolo od osam plesača od kojih je jedan muškarac koji se nalazi u sredini. Zapadna strana ukrašena je motivom scene lova gdje je prikazan konjanik i pas u lovu na jelena. Vrlo je zanimljiv način obrade na dužim stranama (sjevernoj i južnoj), što asocira na "paralelna rebra" ili "brvna" kako ih navodi Bešlagić, koja su do sada bila evidentirana samo na dva stećka u zapadnom dijelu Hercegovine. ${ }^{139}$

Na lokalitetu "Bijeli brig"140 u Velikom Ograđeniku nalazi se nekropola s 10 stećaka od kojih je većina utonula u zemlju i ne vide se ukrasi na njima. Izgleda da su stećci pomaknuti s prvobitnoga položaja prilikom izgradnje puta, te su mnogi od njih zatrpani zemljom. Oni kojima je bilo moguće uzeti dimenzije u obliku su sanduka (4). Vjerojatno se radi o lokalitetu koji je evidentirala N. Miletić u Arheološkome leksikonu Bosne i Hercegovine pod nazivom "Jasenjački brig",

139 O tome više vidjeti u: Š. BEŠLAGić, Stećci - kultura i umjetnost, str. 373-379.

140 Navedeno prema: http://www.katastar.ba/geoportal/preglednik/ (22. 3. 2018.). 
na kojemu također navodi 10 stećaka u obliku sanduka i visokih sanduka, koji su orijentirani u smjeru sz-ji i jz-si. ${ }^{141}$ Nekropola je danas u vrlo lošem stanju.

U Vionici su stećci evidentirani na osam lokaliteta. Prvo navodimo lokalitet "Bare" koji uz Vionicu navode Š. Bešlagić, A. Zelenika i K. Kordić, dok s druge strane M. Vego i R. Jolić te N. Miletić i P. Oreč (Arheološki leksikon Bosne i Hercegovine) uz ovu nekropolu navode Čitluk. ${ }^{142}$ Bešlagić na ovome lokalitetu navodi 5 stećaka od čega razlikuje 4 ploče i 1 križ, a ukrašena su dva stećka (jedna ploča i jedan križ), i to motivima bordure od povijene lozice s trolistovima, arkadama i štitom s mačem. ${ }^{143} \mathrm{Na}$ lokalitetu smo evidentirali 5 stećaka (dvije ploče, 1 sanduk, 1 stup u kombinaciji sa sandukom i 1 stećak utonuo u zemlju na kojemu nema ukrasa). ${ }^{144}$ Četiri su stećka ukraše-

141 Usp. Arheološki leksikon Bosne i Hercegovine, sv. III., str. 299. Kako su rezultati našega terenskoga istraživanja identični onima koje N. Miletić donosi uz lokalitet "Jasenjački brig" (Mali Ograđenik - Gornji), a u blizini ovoga lokaliteta nalazi se zemljišna čestica s nazivom "Jasenjak" može se zaključiti da se radi o istoj nekropoli. Valja spomenuti da se ovaj lokalitet nalazi u polju blizu Donjega Velikoga Ograđenika.

142 Š. Bešlagić, Stećci. Kataloško-topografski pregled, str. 317; Arheološki leksikon Bosne i Hercegovine, sv. III., str. 292; M. Vego, Historija Brotnja od najstarijih vremena do 1878. godine, str. 157; A. ZELENIKA, "Stećci s područja Vionice. Prilog proučavanju prošlosti Brotnja", str. 42-43; K. Kordić, Vionica, str. 158; R. Jolić, Župa Krista Kralja u Čitluku, str. 60-61. U ranijoj literaturi stećak u obliku stupa evidentiran je kao križ, a kao stup ga tek u novije vrijeme navodi Jolić. Također, valja upozoriti na pomalo nejasno lociranje kao i naziv ovoga lokaliteta ("Crkvina") u djelu M. Vege, pa Jolić navodi kako je bolje ovaj lokalitet nazivati "Bare" kako ne bi došlo do zabune s lokalitetom "Crkvina" u Čitlučkom polju, te napominje kako ovaj lokalitet po svom smještaju pripada Vionici, ali ga navodi uz Čitluk jer je ovo područje "dio gradića Čitluka". Prema K. Kordiću ovo srednjovjekovno groblje nalazi se na lokalitetu "Bare-Ploča", a u svojim navodima koristio je izvješće P. Bakule prema kojemu se stećci nalaze u blizini vrela "Ploča". Napominjemo da se prema katastru ovaj lokalitet najvećim dijelom nalazi u Vionici, te manjim dijelom u Krehinu Gracu, a najmanjim dijelom u Čitluku.

143 Š. BEŠlagić, Stećci. Kataloško-topografski pregled, str. 317. Usp. Arheološki leksikon Bosne i Hercegovine, sv. III., str. 291; R. Jolić, Župa Krista Kralja u Čitluku, str. 60-61; K. Kordić, Vionica, str. 158.

144 Mnogi autori, među kojima i Bešlagić, sve ove stećke evidentirali su kao ploče, iako je visina svih ovih stećaka iznad $30 \mathrm{~cm}$. Kako smo spomenuli na početku rada, i ovdje smo učinili odstupanje od navedene klasifikacije, i to za dva stećka. Naime, u našoj evidenciji ploče su stećci sljedećih dimenzija 
na. Jedan sanduk i jedna ploča ukrašeni su bordurom, a na jednome stećku u obliku ploče nalazi se mač sa štitom. Posebno je interesan$\tan \operatorname{stup}^{145}$ (dimenzija $273 \times 65 \times 37 \mathrm{~cm}$ ) koji se među mještanima zove i križ, a nalazi se u kombinaciji sa sandukom (dimenzija $240 \mathrm{x}$ 190 x $50 \mathrm{~cm}$ ). Stup je ukrašen potkovičastim arkadama. Inače, položaj ovih stećaka je u smjeru sz-ji.

Drugi lokalitet evidentirali smo pod nazivom "Bedra". Bešlagić ga je evidentirao pod nazivom "Vioničko groblje" na što je već ranije ukazao R. Jolić navodeći kako se radi o stećcima ispred kuće Nikole Filipovića i u vinogradu pokraj kuće. Dok Bešlagić, kao i N. Miletić i R. Jolić navode kako se na tom lokalitetu nalazi 9 stećaka u obliku sanduka, A. Zelenika i K. Kordić na ovome lokalitetu bilježe "5-6 većih kamenih ulomaka nekog rimskog građevinskog objekta". ${ }^{146}$ Obradom nekropole zabilježili smo 7 stećaka (2 sanduka, 3 stećka utonula u zemlju i dvije rimske spolije). Nema vidljivih ukrasa, a orijentirani su z-i.

Treći lokalitet poznat kao "Vionički stećci" nalazi se na zemljišnoj čestici s nazivom "Vakup". ${ }^{147}$ Do sada su ovaj lokalitet opisali Š. Bešlagić, M. Vego, A. Zelenika, K. Kordić i R. Jolić, a podatke nalazimo i $\mathrm{u}$ Arheološkome leksikonu Bosne i Hercegovine. Nekropola se u dosadašnjoj literaturi spominje pod nazivima "Sajmište", "Vinine", "Broćino groblje", "Vionički stećci" te "Bilobrig" i "Bilobrig (Vinine)", a neki je autori navode uz Krehin Gradac. Prema Bešlagiću na lokalitetu "Vionički stećci" nalazi se 120 stećaka (119 sanduka i 1 sljemenjak), a isti broj bilježe i N. Miletić te R. Jolić, koji navodi da su mnogi stećci zapravo antičke spolije. Vego je na ovome lokalitetu pobrojao 100 stećaka, dok su A. Zelenika i K. Kordić zabilježili 105 stećaka. Prema opisima ovih autora obrada stećaka je nejednaka, a na nekropoli postoji veći broj rimskih spolija i stećaka amorfnih oblika. Bešlagić

265 × 206 × $37 \mathrm{~cm}$, te 178 x 117 x $33 \mathrm{~cm}$, dok smo stećke čije su dimenzije 205 x 262 x $47 \mathrm{~cm}$ i 240 x 190 x $50 \mathrm{~cm}$ evidentirali kao sanduke.

145 Stećci u obliku stupa vrlo su rijetki u Hercegovini, a njihov najveći broj evidentiran je na području istočne Bosne. O tome više u: Š. BEŠLAGIĆ, Stećci - kultura i umjetnost, str. 105.

146 Š. Bešlagić, Stećci. Kataloško-topografski pregled, str. 317; Arheološki leksikon Bosne i Hercegovine, sv. III., str. 307-308; R. Jolić, Župa Krista Kralja u Čitluku, str. 63; A. Zelenika, "Stećci s područja Vionice. Prilog proučavanju prošlosti Brotnja", str. 45; K. Kordić, Vionica, str. 161; IvAn Sivrić, "Groblje Mainovac i područje Bedra", u: Brotnjo. Zbornik, 5, Matica hrvatska Čitluk, Čitluk, 2006., str. 315.

147 http://www.katastar.ba/geoportal/preglednik/ (23. 3. 2018.). 
i Vego navode kako su dva stećka ukrašena motivima križa. ${ }^{148}$ Pregledom lokaliteta evidentirali smo 115 stećaka, od čega jednu ploču, 14 sanduka, 1 sljemenjak, 11 amorfnih, 8 rimskih spolija, a 80 stećaka utonulo je u zemlju. Ukrašeno je 5 stećaka. Naime, gornja ploha jednoga sanduka ukrašena je motivom križa. Također, gornja ploha jednoga sanduka ukrašena je cijelom površinom Andrijinim križem. Gornja ploha jednoga stećka, koji je utonuo u zemlju, ukrašena je križem i okružena bordurom. Jedan sanduk ukrašen je dvama plastično obrađenim križevima. Na jednome sanduku položen je ulomak (najvjerojatnije dio križa), ukrašen vitičastom lozicom koja završava malenim rozetama, a na krakovima uočavamo plastično obrađene rozete. Osim toga, može se reći da je na jednome stećku, koji je djelomično prekriven zemljom, uklesan neki prikaz, ali nije moguće precizno odrediti o kakvu se ukrasu radi. Smjer orijentacije stećaka je z-i.

Na lokalitetu "Stuba" Bešlagić je evidentirao jedan stećak u obliku sanduka koji je bio u sekundarnoj uporabi kao korito za vodu, a lokalitet opisuju također i R. Jolić, A. Zelenika te K. Kordić. ${ }^{149}$ Ovaj stećak ukrašen je motivom trolisne vinove lozice, rozetom i mladim mjesecom, a njegova orijentacija je u smjeru s-j.

148 Š. BeŠlagić, Stećci. Kataloško-topografski pregled, str. 317; M. VEgo, Historija Brotnja od najstarijih vremena do 1878. godine, str. 157; Arheološki leksikon Bosne i Hercegovine, sv. III., str. 305; A. ZELENIKA, "Stećci s područja Vionice. Prilog proučavanju prošlosti Brotnja", str. 44; K. KoRdić, Vionica, str. 160-161; R. Jolić, Župa Krista Kralja u Čitluku, str. 61-62. Valja napomenuti da u Arheološkome leksikonu Bosne i Hercegovine dva imena upućuju na ovaj lokalitet ali imaju sasvim različite podatke. Naime, na lokalitetu "Bilobrig, Vionica" P. Oreč konstatira kako je nemoguće odrediti oblik stećaka na ovoj nekropoli jer su mnogi od njih utonuli u zemlju, a od ukrasa spominje križ i Andrijin križ. S druge strane, N. Miletić donosi podatke za lokalitet s nazivom "Sajmište (Broćino greblje, Vinine) Krehin Gradac" navodeći kako se na nekropoli nalazi 120 stećaka u obliku sanduka, visokih sanduka i sarkofaga orijentiranih uglavnom z-i, a od ukrasa navodi križ. Usp. Arheološki leksikon Bosne i Hercegovine, sv. III., str. 290, 305.

149 Š. BešLagić, Stećci. Kataloško-topografski pregled, str. 317; A. ZeleniKa, "Stećci s područja Vionice. Prilog proučavanju prošlosti Brotnja", str. 46-47; K. Kordić, Vionica, str. 164. Ovaj lokalitet pod nazivom "Gornji Stubo (Stuba)" spominje i Jolić s istim podatcima samo ne navodi motiv vinove lozice. R. Jolıć, Župa Krista Kralja u Čitluku, str. 63. Kako se većina zemljišnih čestica uz ovaj lokalitet zove "Stuba", odlučili smo se za ovaj naziv. Usp. http:// www.katastar.ba/geoportal/preglednik/ (23.3. 2018.). 
Sljedeći lokalitet u Vionici, zasigurno najpoznatiji, jest groblje "Mainovac". ${ }^{150} \mathrm{U}$ ovome starom vionačkom groblju nalazi se veliki stećak (ploča) koji danas služi kao podnica grobljanske kapele. Ukrašen je bordurom od trolisne lozice, štitom s mačem i mladim mjesecom. Zelenika i Kordić navode kako se ovi motivi nalaze na još nekoliko stećaka u Vionici, a Jolić ih uspoređuje sa stećcima na "brijegu Tadije Primorca". ${ }^{151}$ Ovaj je stećak također u Arheološkome leksikonu Bosne i Hercegovine evidentiran "u obliku masivne ploče", a od ukrasa se spominje vitica, štit s mačem i polumjesec. ${ }^{152}$ Obilaskom lokaliteta potvrđen je stećak u obliku ploče (dimenzije 267 x 208 x $38 \mathrm{~cm}$ ), koji je bogato ukrašen vinovom lozom $s$ trolistovima, mačem sa štitom $i$ mladim mjesecom, a postavljen je u smjeru z-i.

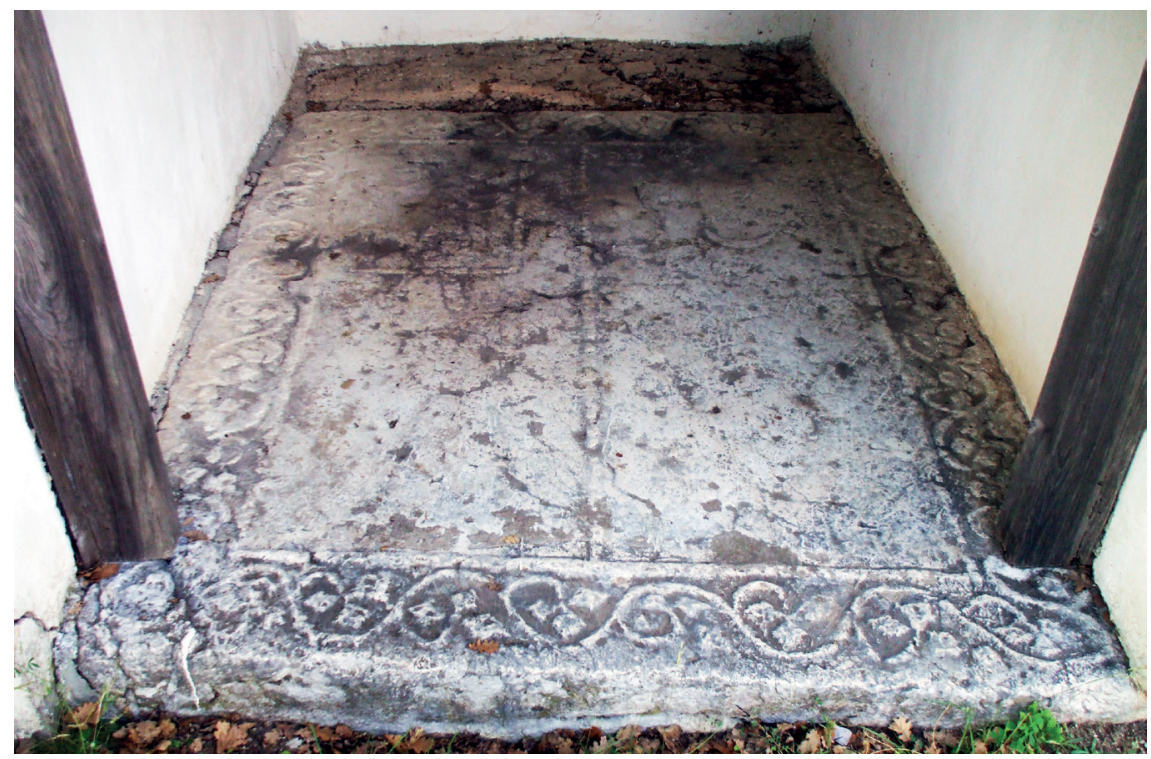

Stećak u kapelici groblja "Mainovac" u Vionici (foto: D. Korać)

150 Groblje Mainovac i područje Bedra kao pretpostavljeno arheološko nalazište u Vionici proglašeno je 2003. godine nacionalnim spomenikom Bosne i Hercegovine. O tome vidjeti u: Ivan Sivrić, "Groblje Mainovac i područje Bedra", u: Brotnjo. Zbornik 5, Matica hrvatska Čitluk, Brotnjo - Čitluk, 2008., str. 309-319.

151 A. Zelenika, "Stećci s područja Vionice. Prilog proučavanju prošlosti Brotnja", str. 45; K. Kondić, Vionica, str. 163; R. Jolıć, Župa Krista Kralja u Čitluku, str. 63-64.

152 Arheološki leksikon Bosne i Hercegovine, sv. III., str. 295. 
Nekropolu pod nazivom "Kordića šuma"153 prvi spominje A. Zelenika, koji navodi 13 stećaka različitih oblika, od kojih je samo jedan ukrašen motivima tordirane trake, kamenice i "jabuke s peteljkom". ${ }^{154}$ Obilaskom lokaliteta evidentirali smo 12 stećaka, od čega 6 ploča, 3 sanduka, te 3 stećka utonula u zemlju. Jedan stećak je ukrašen a riječ je o sanduku ukrašenu tordiranom trakom s koje se spuštaju konveksne loptice. Većina stećaka postavljena je u smjeru z-i, dok je jedan u smjeru j-s, a jedan u smjeru s-i.

Sljedeći lokalitet nalazi se na zemljišnoj čestici s nazivom "Vionica", ${ }^{155}$ a koja se nalazi u vlasništvu obitelji Primorac. O ovome lokalitetu pisali su Š. Bešlagić, M. Vego, N. Miletić, R. Jolić, A. Zelenika i K. Kordić, te zabilježili dva osamljena stećka u obliku velikih ploča, orijentiranih u smjeru z-i koji su dobro obrađeni. Prema njihovim opisima, oba stećka ukrašena su motivima bordure od povijene lozice s trolistovima i motivom štita s mačem. Jolić smatra kako je stećke

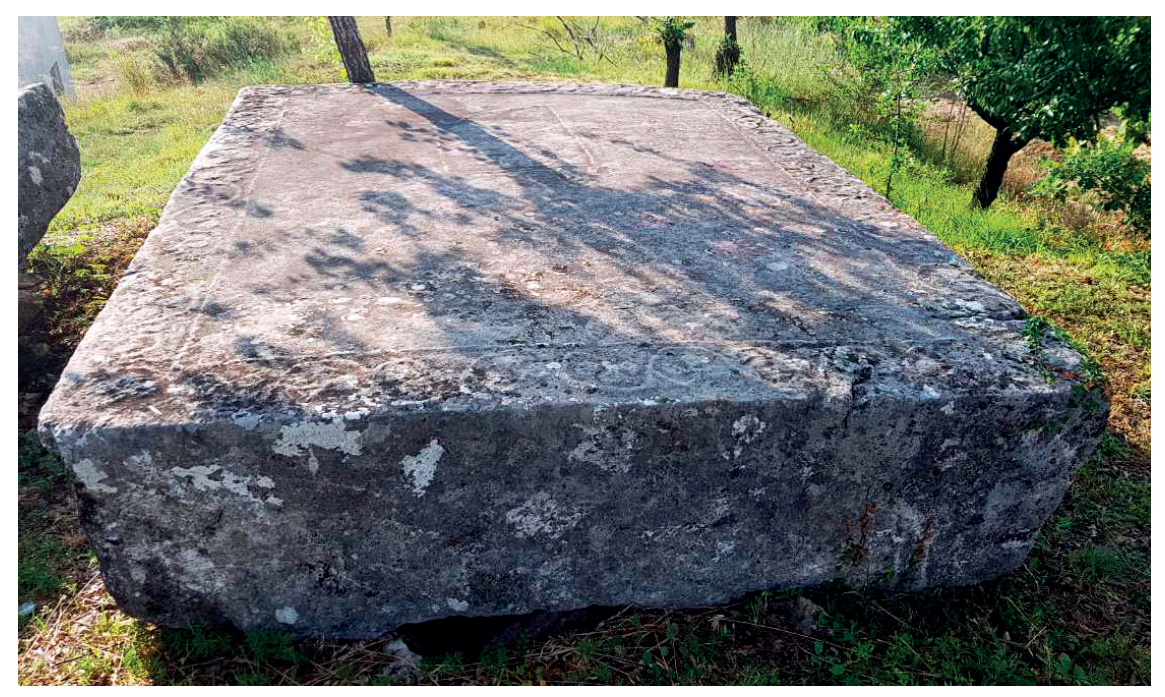

Stećak na lokalitetu "Vionica" (foto: D. Korać)

153 Lokalitet se nalazi na zemljišnoj čestici s nazivom "Vionica". http://www.katastar.ba/geoportal/preglednik/ (23. 3. 2018.).

154 A. Zelenika, "Stećci s područja Vionice. Prilog proučavanju prošlosti Brotnja", str. 47. Iste podatke nalazimo i u: K. Kordić, Vionica, str. 164.

155 Navedeno prema: http://www.katastar.ba/geoportal/preglednik/ (23. 3. 2018.). 
na ovoj nekropoli radio isti majstor kao i stećak Tadije Primorca. ${ }^{156}$ Prilikom obilaska ovoga lokaliteta ustanovljeno je kako prema dimenzijama nije riječ o pločama nego o sanducima $(288 \times 219$ x $45 \mathrm{~cm}$ i 274 x 224 x $64 \mathrm{~cm}$ ). Stećci su orijentirani u smjeru z-i te je potvrđeno kako su ukrašeni bordurom, tordiranom trakom i motivom mača sa štitom. Spomenici su postavljeni u smjeru z-i.

Posljednja nekropola u Vionici poznata je pod imenom "Šumarak". Ovdje je Š. Bešlagić zabilježio 26 stećaka (25 sanduka i 1 sljemenjak) orijentacije z-i, navodeći kako su spomenici oštećeni i utonuli. Prema njegovim navodima ukrašeno je 8 sanduka i 1 sljemenjak, a motivi na stećcima su: tordirana traka, bordura od cik-cak linija, bordura od spiralica, rozeta, mladi mjesec, križ, križ-rozeta, kamenica i štit s mačem. ${ }^{157}$ Prema Vegi nekropola broji 27 stećaka (24 ploče, 2 sanduka i 1 sljemenjak), dok su Zelenika i Kordić zabilježili 21 stećak (16 ploča, 4 sanduka i 1 sljemenjak) od čega je 5 stećaka ukrašeno. ${ }^{158} \mathrm{Te}-$ renskim istraživanjem na ovome lokalitetu evidentirali smo 28 stećaka, od čega 4 sanduka i 1 sljemenjak s postoljem, a ostalim stećcima nismo mogli utvrditi potpune dimenzije. Na stećcima nalazimo sljedeće ukrasne motive: tordirana traka, rozeta, mladi mjesec i mač sa štitom. Ukrašeno je ukupno 7 stećaka. Naime, jedan sanduk ukrašen je tordiranom trakom i motivom mača sa štitom. Sljemenjak s postoljem ukrašen je tordiranom trakom i motivom rozete na istočnoj i zapadnoj strani. Jedan stećak ukrašen je tordiranom trakom i trakom s cik-cak linijama, dok je drugi, utonuo u zemlju, također ukrašen tordiranom trakom te motivom mladoga mjeseca. Tordiranom trakicom na dva dijela podijeljen je još jedan utonuli stećak. Jedan stećak ukrašen je motivom rozete a drugi stećak ukrašen je motivom mladoga mjeseca. Stećci su postavljeni u smjeru z-i.

156 Š. BeŠLAgić, Stećci. Kataloško-topografski pregled, str. 317; M. VEgo, Historija Brotnja od najstarijih vremena do 1878. godine, str. 157; Arheološki leksikon Bosne i Hercegovine, sv. III., str. 307; R. Jolıć, Župa Krista Kralja u Čitluku, str. 62; A. Zelenika, "Stećci s područja Vionice. Prilog proučavanju prošlosti Brotnja", str. 44-45; K. Kordić, Vionica, str. 161.

157 Š. BeŠLAGIĆ, Stećci. Kataloško-topografski pregled, str. 317. Iste podatke s razlikom u broju navedenih ukrasa nalazimo u: Arheološki leksikon Bosne i Hercegovine, sv. III., str. 307.

158 M. Vego, Historija Brotnja od najstarijih vremena do 1878. godine, str. 157158; A. Zelenika, "Stećci s područja Vionice. Prilog proučavanju prošlosti Brotnja", str. 47; K. Kordić, Vionica, str. 164. 
Na kraju, s ciljem dobivanja što jasnije slike o ovim vrijednim srednjovjekovnim spomenicima na području Općine Čitluk donijet ćemo nekoliko grafičkih priloga. Na području Općine Čitluk evidentiran je ukupno 61 lokalitet sa 796 stećaka. Dok u Bosni i Hercegovini na $100 \mathrm{~km}^{2}$ dolazi prosječno 115 stećaka, ${ }^{159}$ na području ove Općine taj broj iznosi 439 stećaka. Na groblja s više od 50 stećaka na području ove Općine odnosi se samo oko 5\% ukupna broja. Naime, radi se samo o 3 lokaliteta, i to "Šolini stećci" (Čitluk), "Grudina" (Krehin Gradac), i "Vionički stećci" (Vionica), a više od 100 stećaka imaju samo dvije navedene nekropole u Krehinu Gracu i Vionici.

U tabeli 1. doneseni su podatci vezani uz broj nekropola i ukupan broj stećaka evidentiranih na području pojedinih naselja u Općini Čitluk, dok su u grafikonima 1 i 2 prikazani postotci zastupljenosti broja lokaliteta sa stećcima kao i postotci ukupna broja stećaka prema naseljima ove Općine. Iz navedenih podataka može se vidjeti da je u gotovo svakom naseljenom mjestu Općine Čitluk evidentiran barem jedan lokalitet sa stećcima, ali također evidentne su i velike razlike u broju lokaliteta kao i u ukupnu broju evidentiranih stećaka između pojedinih naselja. ${ }^{160} \mathrm{Iz}$ tabele je također evidentno da više naselja ove Općine ima samo jedan lokalitet sa stećcima dok je najveći broj lokaliteta evidentiran u Vionici (8). S druge strane, manje od 10 ovih nadgrobnih spomenika zabilježeno je u Biletić Polju (2), Blatnici (3), Blizancima (6), Čalićima (4), Gradnićima (9), Krućevićima (7) te Međugorju (2). Više od 50 stećaka zabilježeno je u samo pet naselja, i to Citluku (78), Krehinu Gracu (157), Služnju (66), Velikom Ograđeniku (58) te najviše u Vionici (171). Zanimljiva je činjenica da se više od 50\% stećaka nalazi u susjednim naseljima Krehinu Gracu, Čitluku i Vionici, dok je najmanja zastupljenost broja stećaka (manje od 1\%) evidentirana u naseljima Biletić Polje, Blatnica i Međugorje (grafikon 2).

159 Š. BEŠLAGić, Stećci - kultura i umjetnost, str. 68-69. Bešlagić u ovome djelu navodi da gustoća stećaka na području Općine Čitluk iznosi 342 stećka na $100 \mathrm{~km}^{2}$.

160 Tijekom terenskoga istraživanja od pomoći su nam bili Ljilja Mirković, Marija Pehar, Marija Marinčić, Mirela Korać, Miro Tadić, Milan Mirković, Dragan Kozina, Grgo Kozina, Rade Šantić, Dražan Korać, Šimun Korać i Dario Martinović, kojima ovom prilikom najiskrenije zahvaljujemo. 
Dijana Korać - Ružica Mirković - Stećci u Općini Čitluk

\begin{tabular}{|l|l|l|}
\hline Naselje & Broj lokaliteta & Broj stećaka \\
\hline Biletić Polje & 1 & 2 \\
\hline Blatnica & 2 & 3 \\
\hline Blizanci & 2 & 6 \\
\hline Čalići & 1 & 4 \\
\hline Čerin & 3 & 24 \\
\hline Čitluk & 5 & 78 \\
\hline Dobro Selo & 1 & 19 \\
\hline Dragićina & 3 & 38 \\
\hline Gradnići & 4 & 9 \\
\hline Hamzići & 6 & 15 \\
\hline Krehin Gradac & 4 & 158 \\
\hline Krućevići & 1 & 7 \\
\hline Mali Ograđenik & 3 & 42 \\
\hline Međugorje & 2 & 2 \\
\hline Paoča & 5 & 23 \\
\hline Služanj & 4 & 67 \\
\hline Tepčići & 1 & 37 \\
\hline Tepčići Polje & 1 & 33 \\
\hline Veliki Ograđenik & 4 & 58 \\
\hline Vionica & 8 & 791 \\
\hline Ukupno & $\mathbf{6 1}$ & \\
\hline & & 796 \\
\hline
\end{tabular}

Tabela 1. Broj evidentiranih lokaliteta i broj stećaka u naseljima Općine Čitluk 


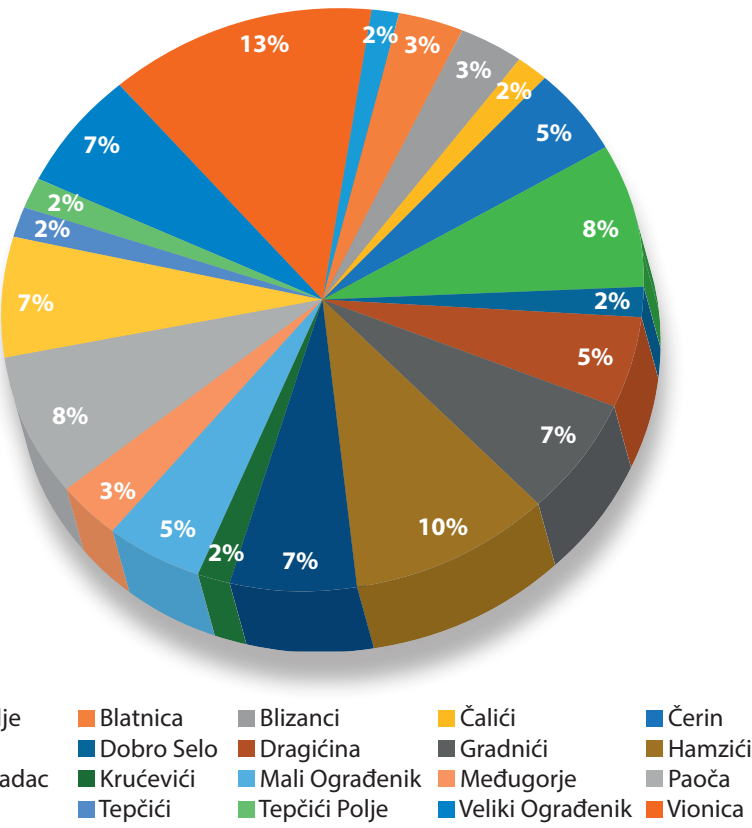

\section{Grafikon 1. Zastupljenost lokaliteta sa stećcima prema naseljima u Općini Čitluk}

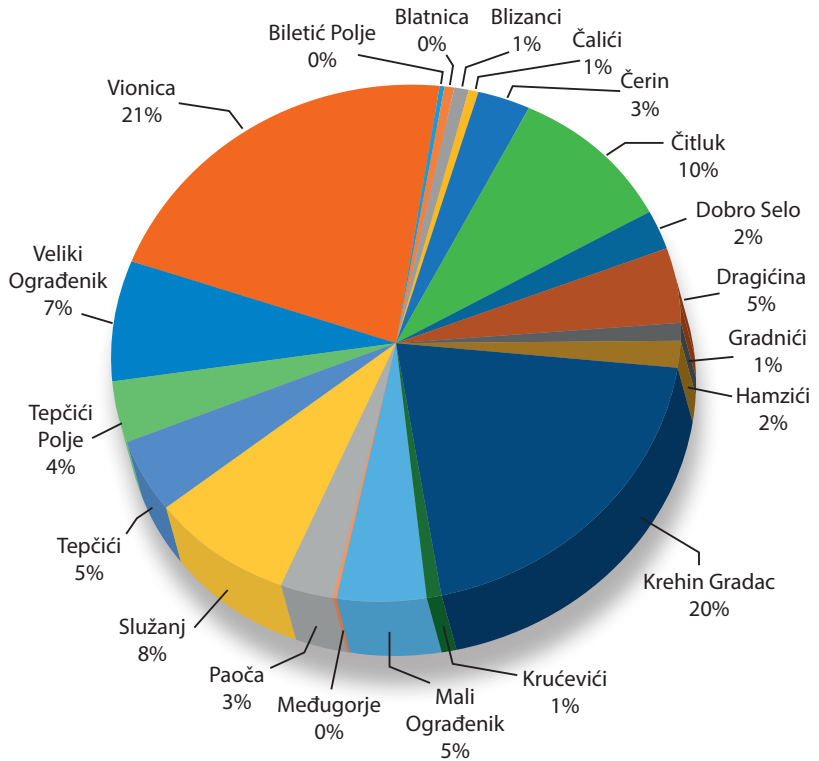

Biletić Polje
Blatnica
Blizanci
Čalići
Čerin
Čitluk
Dobro Selo
Dragićina
Gradnići
Hamzići
Krehin Gradac
Krućevići
Mali Ograđenik
Međugorje
Paoča
Služanj
Tepčići
Tepčići Polje
Veliki Ograđenik
Vionica

Grafikon 2. Zastupljenost broja stećaka prema naseljima u Općini Čitluk 
Od 796 stećaka evidentiranih na području Općine Čitluk samo za 407 stećaka (oko 51\%) bilo je moguće odrediti njihov oblik, dok su 389 evidentirana stećka zarasla u nepristupačno šiblje ili utonula u zemlju. S obzirom na ovu činjenicu mišljenja smo da bi detaljnija analiza zastupljenosti pojedinih oblika stećaka u ovoj Općini bila nepotpuna, pa ćemo stoga iznijeti samo podatke koji se odnose na broj klasificiranih oblika stećaka. Od 407 stećaka kojima je na terenu bilo moguće uzeti dimenzije zastupljenost pojedinih oblika je sljedeća: stećaka u obliku ploče (74), sanduka (217), sanduka s postoljem (4), visokih sanduka s postoljem (3), sljemenjaka (16), sljemenjaka s postoljem (7), jedan jedinstven primjer dva sljemenjaka na jednom postolju, dva križa (jedan u kombinaciji s pločom, a jedan u kombinaciji sa sandukom), jedan stup (u kombinaciji sa sandukom), amorfnih (59), rimskih spolija (10), te 7 stećaka u sekundarnoj uporabi kao korita za vodu, a 6 ugrađenih u zidove. S obzirom na navedene podatke može se pretpostaviti da je i na području ove Općine najviše stećaka u obliku sanduka. Pri tome valja imati na umu da je na području Bosne i Hercegovine, prema analizi Š. Bešlagića, od ukupna broja stećaka oko $64 \%$ u obliku sanduka, dok je ploča oko $21 \%$, sljemenjaka $9 \%$ a križeva $0,5 \% .{ }^{161}$

Vrlo je zanimljiv i podatak koji se odnosi na ukrašenost stećaka na području ove Općine. Naime, ukrasni motivi evidentirani su na 104 stećka, što čini oko $13 \%$ od ukupna broja stećaka, ali pri tome treba imati na umu velik broj nepristupačnih stećaka pa je ukrašenost stećaka zasigurno još mnogo veća. Na stećcima nalazimo različite ukrasne motive koji se ne razlikuju od motiva u drugim krajevima Bosne i Hercegovine. Kako ukrasi na stećcima nisu u fokusu ovoga rada, spomenut ćemo još samo zastupljenost ukrasnih motiva na pojedinim oblicima stećaka. Evidentirana su 44 ukrašena sanduka, 2 sanduka s postoljem, 3 visoka sanduka s postoljem, 26 ploča, 6 sljemenjaka, 6 sljemenjaka s postoljem, jedan jedinstven primjer dva sljemenjaka na jednome postolju, jedan križ u kombinaciji s pločom a jedan u kombinaciji sa sandukom, jedan stup (u kombinaciji sa sandukom), 11 utonulih u zemlju, te dva u sekundarnoj uporabi kao korita. Važno je imati na umu i da se na stećcima Općine Čitluk nalazi ukupno 8 natpisa, od kojih su 4 evidentirana na nekropoli "Visočica" u Velikom Ograđeniku, a ostala 4 natpisa nalaze se u Čerinu, Paoči, Gradnićima, te u Služnju.

161 Š. BEŠLAGIĆ, Stećci - kultura i umjetnost, str. 84, 86, 98, 111. 
Hercegovina - 4 - 2018., str. 117-172

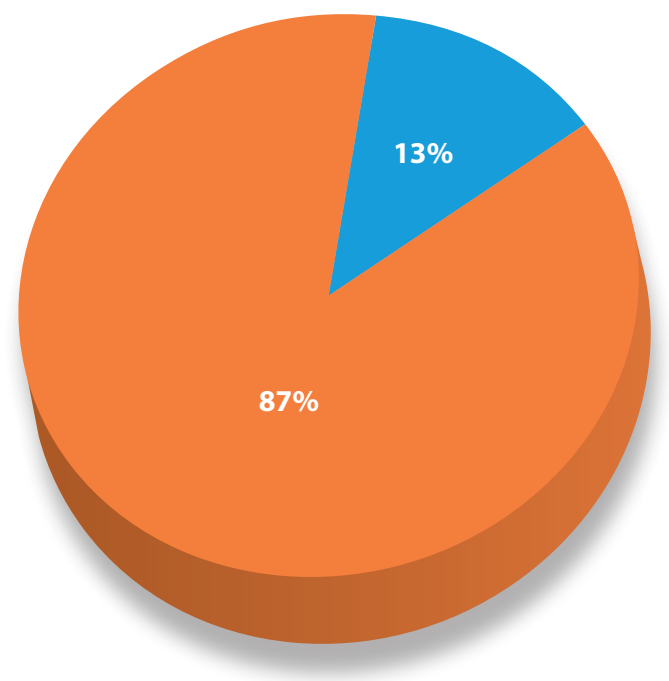

- Stećci s ukrasnim motivima

- Stećci bez ukrasnih motiva

Grafikon 3. Zastupljenost ukrasnih motiva na stećcima u Općini Čitluk

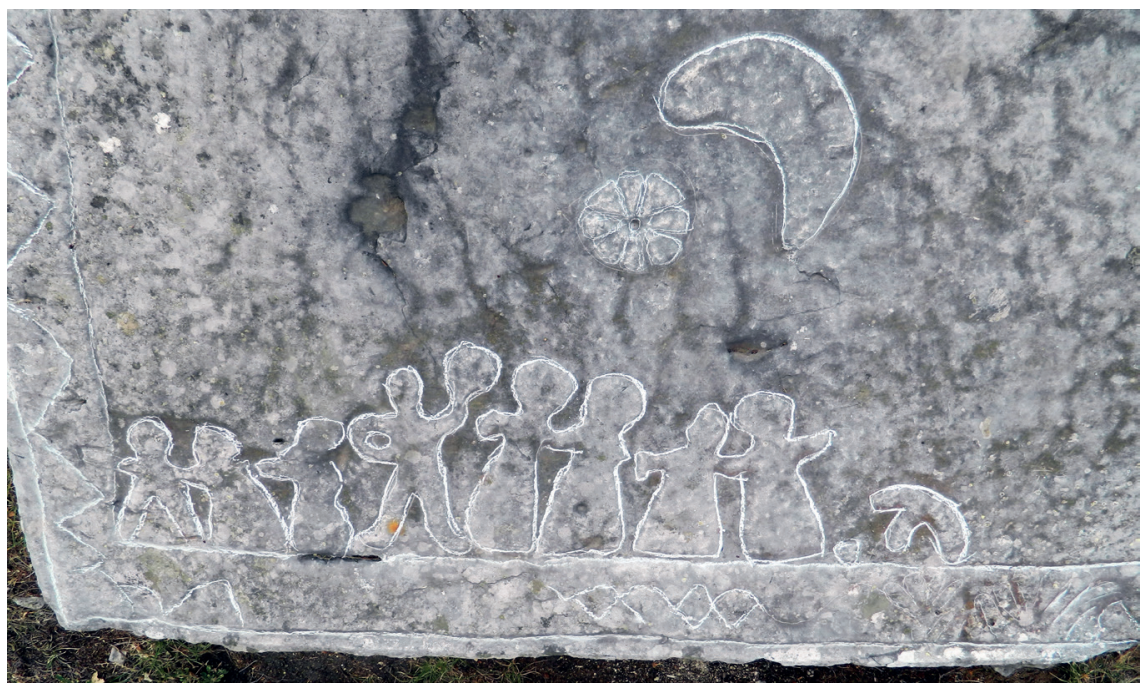

Ukrasni motivi na stećku u groblju "Čmarevac" (foto: D. Korać) 
Dijana Korać - Ružica Mirković - Stećci u Općini Čitluk

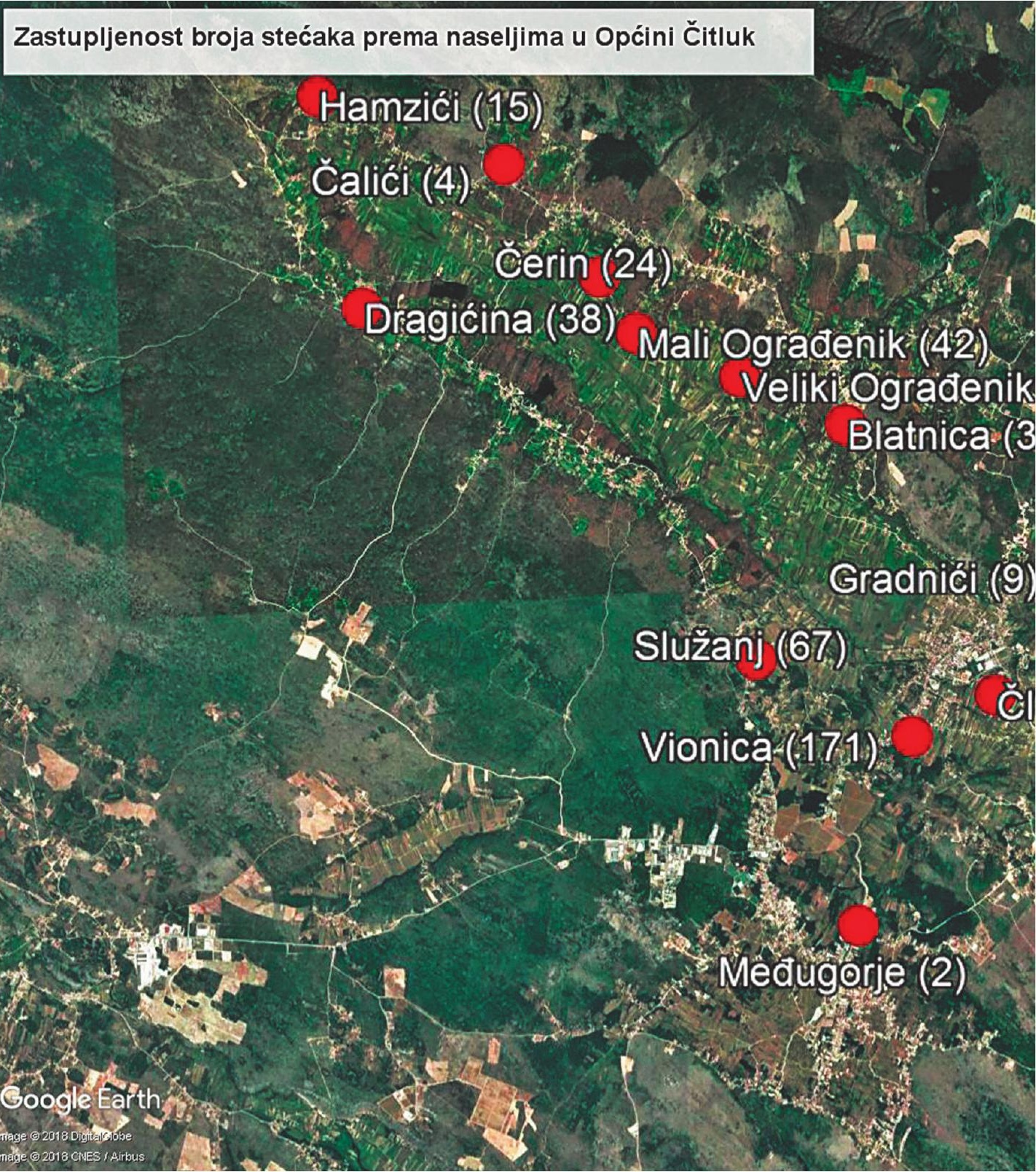




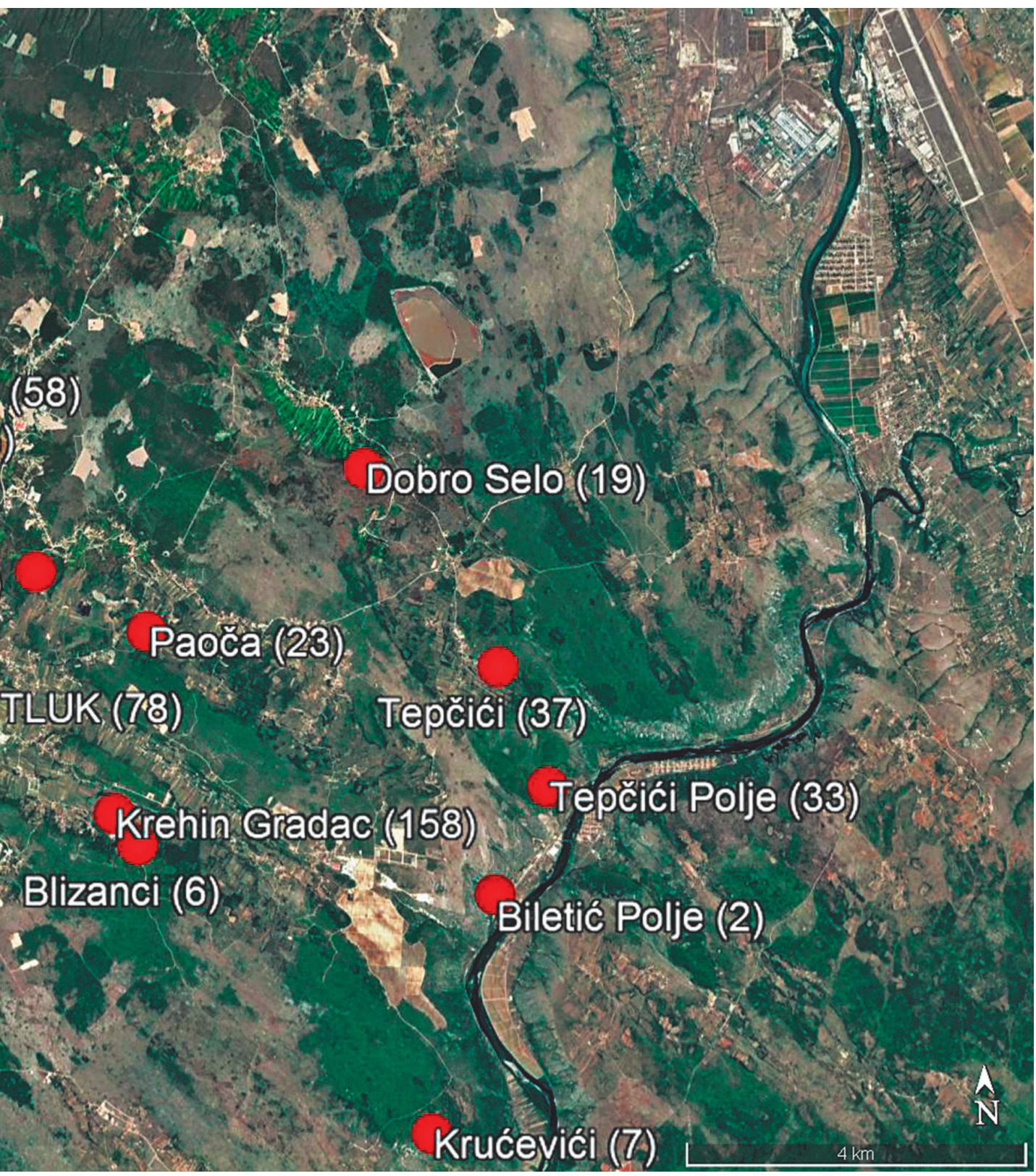




\section{Zaključak}

Pretpostavka da se ukupan broj nekropola i stećaka u Općini Čitluk razlikuje od dosadašnjega broja u literaturi revidiranjem je potvrđena. Naime, prema popisu Š. Bešlagića u Općini Čitluk nalaze se 32 lokaliteta s ukupno 703 stećka, a u Arheološkome leksikonu Bosne i Hercegovine na području ove Općine spominju se 44 lokaliteta sa 655 srednjovjekovnih nadgrobnih spomenika. Terenskim istraživanjem zabilježili smo 61 lokalitet sa 796 stećaka, ali ni ovaj broj zasigurno nije konačan jer su, na žalost, neke nekropole u veoma zapuštenu stanju, pa nije postojala mogućnost pristupa svim stećcima. Mišljenja smo da na ovome području ima još stećaka, nepoznatih široj javnosti ali poznatih nekim pojedincima koji će pomoći u daljnjim popisima i istraživanju ovih vrijednih srednjovjekovnih spomenika. Također treba imati na umu da je tijekom vremena jedan broj stećaka iskorišten u sekundarne svrhe, neki su odneseni u pojedine muzeje pa je prije nekoliko desetljeća, kada su provedena ranija istraživanja, njihov broj na ovome području bio zasigurno mnogo veći nego danas.

$\mathrm{Na}$ kraju, možemo konstatirati da bi revidiranje broja ovih spomenika i u drugim općinama zasigurno dovelo do sličnih rezultata što pokazuju i istraživanja u Općini Široki Brijeg, gdje je veoma izražena razlika u broju nekropola kao i broju stećaka u odnosu na rezultate koje je ranije iznio Š. Bešlagić. Naime, na području ove Općine I. Dugandžić evidentirao je 60 lokaliteta s 821 stećkom, dok je prema popisu Š. Bešlagića navedena 41 nekropola s 597 stećaka. ${ }^{162}$

162 Ivan Dugandžić, Širokobriješka baština, Matica hrvatska Široki Brijeg, Široki Brijeg, 2004., str. 50. 


\title{
Stecaks in the Municipality of Citluk
}

\author{
Summary
}

The assumption that the total number of necropolis and stecaks in the municipality of Citluk differs from the number previously mentioned in literature has been confirmed by the revision. Namely, according to S. Beslagic's list, there are 32 sites in the municipality of Citluk with a total of 703 tombstones, whereas in the Archaeological Lexicon of Bosnia and Herzegovina there are 44 localities with 655 medieval tombstones found in this area. Field research in this area recorded 61 localities with 796 stecaks, but this number is certainly not final as, unfortunately, some necropolises have been neglected and could not be reached due to the inaccessible terrain.

In Bosnia and Herzegovina, according to S. Beslagic's research, on $115 \mathrm{~km}$ there are approximately 100 stecaks in the area of this municipality, while according to our research, there are 439 stecaks. The cemeteries with less than 50 stecaks, make $5 \%$ of the total number. Several settlements of this municipality have only one locality with stecaks, while the largest number of localities is recorded in Vionica (8). More than 50 tombstones were recorded only in five settlements: Citluk (78), Krehin Gradac (157), Sluzanj (66), Veliki Ogradenik (58) and most in Vionica (171). Interestingly, more than $50 \%$ of these monuments is found in the neighbouring settlements of Krehin Gradac, Citluk and Vionica.

Of 407 stecaks (about 51\%), which could be measured on the terrain, the following forms were found: plate-shaped stecak (74), chest (217), chest with stand (4), tall chests with stand (3), gabled tombstone (16), gabled tombstone with stand (7), a unique example of two gabled tombstones on one stand, 2 crosses (one in combination with a slab and another in combination with a chest), one pillar (in combination with a chest), the amorphous (59) Roman spolias (10), and 7 stecaks of secondary use as water troughs and 6 built into walls. Decorative motifs are recorded on 104 stecaks, which makes about $13 \%$ of the total number of tombstones. There are 44 decorated chests, 2 chests with stand, 3 tall chests with stand, 26 slabs, 6 gabled tombstones, 6 gabled tombstones with stand, a unique example of two gabled tombstones on one stand, one cross in combination with a slab and one in 
combination with a chest, one pillar (combined with a chest), 11 sunk into the earth, and two in secondary use as troughs. There are 8 inscriptions found on the stecaks of Citluk municipality, 4 of which are recorded in the necropolis of Komlinovic, and the remaining 4 inscriptions are located in Cerin, Paoca, Gradnici, and Sluzanj.

Keywords: Citluk; Brotnjo; tombstones; shapes of stecak; necropolis. 